\title{
ФАДЕЕВА Т.С.
}

ДИСПЛАЗИЯ

СОЕДИНИТЕЛЬНОЙ ТКАНИ: НОВЫЕ ГОРИЗОНТЫ ПРОБЛЕМЫ

\section{МОНОГРАФИЯ}

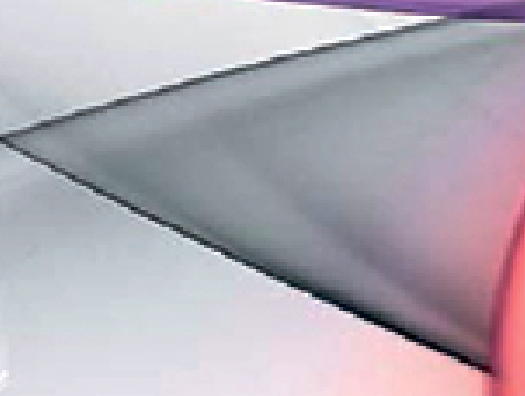

Чебоксары 2018 


\section{Т.С. Фадеева}

\section{Дисплазия соединительной ткани: новые горизонты проблемы}

Монография

Чебоксары 2018 


\section{Рецензент: \\ Кисляков Валерий Александрович}

д-р мед. наук, заведующий отделением гнойной хирургии

ГБУЗ «Городская клиническая больница им. А.К. Ерамишанцева Департамента здравоохранения г. Москвы», Член Европейской ассоциации сосудистых хирургов, Член Европейской Академии Естествознания, Заслуженный деятель науки и образования РАЕ

Фадеева, Т. С.

Ф15 Дисплазия соединительной ткани: новые горизонты проблемы : монография / Т. С. Фадеева. - Чебоксары: ИД «Среда», 2018. - 76 с.

\section{ISBN 978-5-6042304-4-2}

В работе поднимаются вопросы прогнозирования осложнений беременности и родов и неблагоприятных состояний у плода при наличии НДСТ у будущей матери, которые также нуждаются в изучении, особенно с позиций математического моделирования заболевания. Необходима и разработка единой тактики оказания медико-социальной помощи и лечебно-диагностических услуг беременным женщинам, страдающим НДСТ, что позволит сделать исход родов более благоприятным и улучшит последующий прогноз для матери и новорожденного. В литературе практически отсутствует оценка течения беременности и исхода родов в зависимости от степени тяжести НДСТ. Мало сведений и о роли маркера метаболизма соединительной ткани - оксипролина, микроэлементов (магния) и витаминов (D3) у беременных, страдающих НДСТ, соответственно четко не сформулирована врачебная тактика в отношении таких больных. Несмотря на многочисленные успехи в исследовании причин возникновения осложнений во время беременности и родов у женщин, страдающих НДСТ, до сих пор так и не выработан единый подход к их ведению на дородовом этапе. Поэтому все большую актуальность приобретают вопросы поиска возможных предикторов для своевременного предсказания неблагоприятного течения беременности и исхода родов у таких пациенток. Это позволит разработать оптимальную организационно-методологическую базу и в последующем улучшить прогноз для женщин и их потомства.

Таким образом, в отличие от имеющегося стандартного подхода, нами предложено комплексное ведение пациенток, страдающих НДСТ, включающее своевременное выявление пациенток из группы риска, уточнение их состояния с помощью таких маркеров, как магний и оксипролин, дополнительный прием препаратов магния и витамина D. Оптимальный план ведения периода гестации, родов и патогенетически аргументированный комплекс лечебно-профилактических мероприятий для рожениц, страдающих НДСТ, позволят не только улучшить исходы беременности и родов, но и способствуют укреплению здоровья будущего поколения. 1. НДСТ оказывает влияние на течение беременности, родов и состояние новорожденного. Степень воздействия во многом определяется тяжестью основного заболевания. При тяжелом течении НДСТ достоверно выше была распространенность спонтанного выкидыша и преждевременных родов, в послеродовом периоде чаще наблюдался эндометрит и анемия тяжелой степени. У плода чаще встречалась тяжелая асфиксия по шкале Апгар на 1-й и 5-й минуте, врожденные пороки сердца, морфофункциональная незрелость, конъюгационная желтуха и судорожный синдром. 2. Низкое содержание магния и оксипролина ассоциировано с возникновением осложнений в родах и снижением антропометрических характеристик новорожденного. Приём препаратов магния достоверно влияет на концентрацию данного микроэлемента и оксипролина в крови беременных женщин, страдающих НДСТ. 3. Терапия препаратами магния является эффективным средством у пациенток, страдающих НДСТ, так как способствует улучшению самочувствия во время беременности, улучшает течение послеродового периода и уменьшает распространённость хронической внутриутробной гипоксии плода. 4. Прием витамина D и препаратов магния, благотворно влияет на течение беременности и состояние плода, снижая распространённость преэклампсии и хронической внутриутробной гипоксии плода, уменьшая встречаемость морфофункциональной незрелости и конъюгационной желтухи новорожденного. 5. Созданная программа для ЭBM «STEP DST» может быть применена в клинической практике врачей акушеров-гинекологов и организаторов здравоохранения. Получаемый индивидуальный прогноз вероятности развития осложнений репродукции позволяет наметить оптимальный план ведения периода гестации, родов и послеродового периода, назначить патогенетически обоснованный комплекс лечебно-профилактических мероприятий женщинам, страдающим НДСТ.

ISBN 978-5-6042304-4-2

DOI $10.31483 / \mathrm{a}-52$

DOI $10.31483 / \mathrm{r}-22132$

(C) Т.С. Фадеева, 2018

(С) ИД «Среда», 2018 


\section{ОГЛАВЛЕНИЕ}

Предисловие.......................................................................... 4

Глава 1. Теоретические основы оценки течения беременности, исхода родов для матери и плода при недифференцированной дисплазии соединительной ткани .............................................. 7

1.1. Основные характеристики дисплазии соединительной ткани, еe классификация ................................................................. 7

1.2. Симптомы дисплазии соединительной ткани.................... 14

1.3. Дисплазия соединительной ткани и беременность ............ 17

1.4. Недифференцированная дисплазия соединительной ткани как патология в гинекологии и акушерстве.............................. 23

Глава 2. Методы исследования течения беременности у женщин, связанные с недифференцированной дисплазией соединитель-

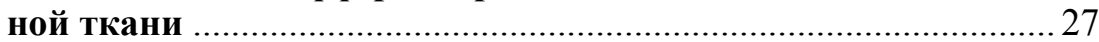

2.1. Исследование фенотипических признаков недифференцированной дисплазии соединительной ткани ............................. 27

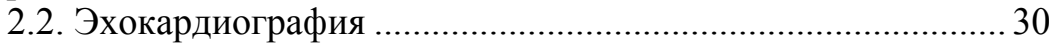

2.3. Биохимический анализ крови........................................... 32

Глава 3. Математическое прогнозирование течения родов у женщин с дисплазией соединительной ткани....................................... 37

3.1. Компьютерная программа «Шаг к DST» ........................... 38

3.2. Проверка пакета программного обеспечения, разработанного Т.С. Фадеевой .................................................................. 38

Глава 4. Оптимизация мер ведения беременности и родов у женщин с дисплазией соединительной ткани .........................5 54

4.1. Система профилактических мер по охране репродуктивного

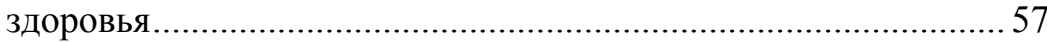

4.2. Течение беременности и родов у женщин с недифференцированной дисплазией соединительной ткани ............................6 60 4.3. Алгоритм ведения беременности и родов у женщин с недифференцированной дисплазией соединительной ткани.............. 62 Глава 5. Схема ведения беременности женщин с недифференцированной дисплазией соединительной ткани.......................66

5.1. Ведение беременности условно здоровой женщины.........66

5.2. Ведение женщины, которая знала до беременности, что она больна дисплазией соединительной ткани .............................. 69 5.3. Тактика ведения беременности и родов у женщин с недифференцированной дисплазией соединительной ткани....... 73 


\section{ПРЕДИСЛОВИЕ}

В настоящее время вопрос здоровья населения является наиболее актуальным для полноценного развития любой страны. В связи с этим проблемы здоровья беременных, заболеваемость новорожденных и предотвращение летального исхода родов для матери или ребенка были и остаются приоритетными. Но, несмотря на данный факт, отмечается рост осложнений беременности, заболеваемости младенцев и беременных, что неминуемо приводит к осложнениям родов и пагубно сказывается на демографическом росте населения страны.

Все это требует в настоящее время внедрение и повышение эффективности существующих методов и мер медико-социальной помощи беременным женщинам, которая понимается как комплексная система мер медицинского, психолого-педагогического и социального характера, необходимых для восстановления, сохранения и укрепления здоровья как беременных женщин, так и в первые дни материнства.

Однако все это неразрывно связано с изучением экстрагенитальных патологий женщин и их влиянием на протекание беременности и родов, что в свою очередь является основным направлением современного акушерства. Именно данные патологии женщин, как указывают в своих работах многие авторы, могут привести к перинатальным заболеваниям и смертности во время родов.

Особое внимание в настоящее время уделяется изучению экстрагенитальных патологий женщин, связанных с недифференцированной дисплазией соединительной ткани.

На сегодня исследованию экстрагенитальных патологий женщин, связанных с недифференцированной дисплазией соединительной ткани, посвятили свои работы такие ученые, как Г.И. Прохоренко, Л.Г. Назаренко, Т.С. Фадеев, Т.С. Лукина, М.Е. Евсеева, В.А. Аксененко, О.В. Сергеева, О.В. Козинова, М.М. Шехтман, В.И. Маколкин и другие. Но все же в настоящее время существует недостаточная изученность данных экстрагенитальных патологий женщин. Все существующие работы ограничены конкретной стороной проблемы, но не дают полной клинической и методологической картины, что, в свою очередь, не позволяет эффективно оце- 
нить ситуацию во время дородовой подготовки беременных с недифференцированной дисплазией соединительной ткани и порождает необходимость создания обобщающего научного труда.

Следовательно, актуальность данной работы заключается в создании обобщающего научного труда, который позволит оптимизировать и выявить медико-организационные мероприятия по улучшению качества и эффективности дородовой подготовки беременных женщин с недифференцированной дисплазией соединительной ткани.

Теоретическая значимость данной работы состоит в анализе всей существующей литературы по данной проблеме, ее обобщении, полном раскрытии основных аспектов, которые предназначены для оптимизации и определения медико-организационных мероприятий по улучшению качества и эффективности дородовой подготовки беременных женщин с недифференцированной дисплазией соединительной ткани.

Практическая значимость заключается в применении систематизированных данных для дальнейших исследований и для повышения эффективности и качества оказания медико-социальной помощи при дородовой подготовке беременных женщин с недифференцированной дисплазией соединительной ткани.

Кроме того, в данной работе изложены медико-организационные мероприятия по улучшению качества и эффективности дородовой подготовки беременных женщин с недифференцированной дисплазией соединительной ткани, на которые могут ориентироваться руководители органов и учреждений здравоохранения, молодые специалисты, акушеры и гинекологи, благодаря чему будет достигнута координация действий при оказании медицинской помощи беременным женщинам.

Изложение материала в работе основывается на следующих методологических принципах:

- дородовой подготовке беременных женщин с недифференцированной дисплазией соединительной ткани;

- принцип объективности предполагает опору на факты, классификации, существующую статистику;

- принцип системности, который заключается в рассмотрении предмета исследования во взаимосвязи всех его элементов и в его внешних связях. 
Необходимость изложения материала структурно и последовательно потребовала применения следующих методов исследования: анализ, классификация и обобщение теоретических положений, прогнозирование, систематизация данных.

Структура работы. Работа состоит из предисловия, четырех глав (включающих в себя подглавы), заключения, списка использованной литературы и приложений.

Первая глава посвящена обзору литературы, определению понятия «дисплазия соединительной ткани», рассмотрению ее классификации и симптомов. Кроме того, анализируются молекулярные механизмы влияния магния на недифференцированную дисплазию соединительной ткани.

В рамках второй главы раскрываются основные методы выявления недифференцированной дисплазии соединительной ткани, которые лежат в основе медико-организационных мероприятий по улучшению качества и эффективности дородовой подготовки беременных женщин с недифференцированной дисплазией соединительной ткани.

В третьей главе описывается синдром дисплазии соединительной ткани у женщин детородного возраста, анализируются статистические данные распространенности данного синдрома.

Четвертая глава основывается на описании течения беременности при недифференцированной дисплазии соединительной ткани, способах прогнозирования беременности и исхода родов при недифференцированной дисплазии соединительной ткани (математическое прогнозирование, мониторинг вариабельности ритма сердца). Особое внимание уделяется изучению назначения, эффективности этиопатогенетической терапии для беременных женщин с недифференцированной дисплазией соединительной ткани.

В заключении тезисно подводятся итоги работы и дается ряд необходимых рекомендаций для молодых специалистов, акушеров и гинекологов.

Список использованной литературы составляет $\underline{43}$ источника, из них $\underline{21}$ отечественный и $\underline{22}$ зарубежных источника. 
Глава 1. Теоретические основы оценки течения беременности, исхода родов для матери и плода при недифференцированной дисплазии соединительной ткани

\section{ГЛАВА 1. ТЕОРЕТИЧЕСКИЕ ОСНОВЫ ОЦЕНКИ ТЕЧЕНИЯ БЕРЕМЕННОСТИ, ИСХОДА РОДОВ ДЛЯ МАТЕРИ И ПЛОДА ПРИ НЕДИФФЕРЕНЦИРОВАННОЙ ДИСПЛАЗИИ СОЕДИНИТЕЛЬНОЙ ТКАНИ}

В настоящее время проблема недифференцированной дисплазии соединительной ткани является очень актуальной, так как отмечается широкое распространение данной патологии среди женщин репродуктивного возраста, что примерно равно $20-30 \%$ от общего числа женщин, однако на данный момент отмечается рост числа больных дисплазией соединительной ткани. Раннее выявление данной патологии необходимо для оценки течения беременности и исхода родов для матери и ребенка.

\section{1. ОСНОВНЫЕ ХАРАКТЕРИСТИКИ ДИСПЛАЗИИ СОЕДИНИТЕЛЬНОЙ ТКАНИ, ЕЕ КЛАССИФИКАЦИЯ}

Соединительная ткань составляет около $50 \%$ от общей массы человека, она является одной из четырех типов тканей, к числу которых относятся мышечная, эпителиальная, нервная. В организме человека она выполняет разнообразные функции, среди которых: барьерная, морфологическая, пластическая и трофическая. Однако основной функцией соединительной ткани является структурная поддержка всех других типов ткани. К соединительной ткани относят хрящи и кости, она может подразделяться на ареолярную соединительную ткань, которая необходима для скрепления органов, и плотную соединительную ткань, которая образует связки и сухожилия.

Главным отличием соединительной ткани от других типов является избыток внеклеточной матрицы, но при этом наблюдается сравнительно малое число клеток, образующих ткань. В молекулярной биологии внеклеточная матрица (ВКМ) трактуется как сложная сеть, образованная многочисленными структурными мак- 
ромолекулами (протеогликаны, коллагены и эластин). При взаимодействии с другими структурными макромолекулами поддерживается целостность тканей ${ }^{1}$.

Матрица формирует своеобразную организованную среду, в рамках которой мигрирующие клетки могут перемещаться и взаимодействовать друг с другом. Все макромолекулы, формирующие ВКМ, образуются клетками в матрице. В большинстве соединительных тканей матричные макромолекулы производятся фибробластами, а в специализированных типах соединительной ткани, таких, например, как хрящ и кость - хондробластами и остеобластами. ВКМ включает в себя три компонента: гелеобразная среда, коллагеновые волокна и эластиновые волокна. Рассмотрим каждый из компонентов последовательно.

Гелеобразная среда является самым важным компонентом внеклеточной матрицы, которая образуется протеогликанами, которые, в свою очередь, представлены вытянутыми полипептидными цепями с многочисленными полисахаридными цепями глюкозаминогликанов, соединённых ковалентными связями.

Многочисленные цепи протеогликанов соединяются с глюкозаминогликаном - полимером гиалуроновой кислоты, именуемым гиалуронаном. Нити гиалуронана скрепляют структуру геля в единое целое, и этот полисахаридный «гель» может противостоять сжатию и растяжению ВКМ и способствовать быстрой диффузии питательных веществ, строительных материалов и гормонов между кровью и клетками соединительной ткани.

Механически структура геля включает в себя три типа волокон:

1) коллагеновые волокна (в составе которых присутствует коллаген I), они образуют скелет соединительной ткани;

2) гибкие волокна (в составе которых присутствует эластин и фибриллин), они отвечают за эластичность ткани;

3) сетчатые (или ретикулярные) волокна (в составе которых присутствует коллаген III), они формируют перекрестные связи между всеми другими волокнами и держат вместе все остальные компоненты ткани.

\footnotetext{
${ }^{1}$ Головской Б.В. Особенности клинического проявления дисплазии соединительной ткани у лиц трудоспособного возраста / Б.В. Головской, Л.В. Усольцева, Я.В. Ховаева, Н.В. Иванова // Клин. мед. - 2002. - №80 (12). - С. 39-41.
} 
Глава 1. Теоретические основы оценки течения беременности, исхода родов для матери и плода при недифференцированной дисплазии соединительной ткани

Гелеобразная субстанция ВКМ образована протеогликанами и многодоменными гликобелками. Протеогликаны соединяются нитями гиалуронана, каждая из которых содержит более 25 тыс. мономеров гиалуроновой кислоты. Каждая нить может иметь длину несколько десятков микрон. Гиалуронан синтезируется благодаря гиалуронансинтетазам (гены HAS1, HAS2 и HAS3) и деградируется посредством гиалуронидаз (гены HYAL2, HYAL3, HYAL4 и HYALP).

Протеогликаны включают в себя длинные цепочки полисахаридов, которые при физиологических условиях отрицательно заряжены, так как они имеют ковалентное соединение с сульфатом и уронатами. Для каждого типа протеогликана есть многочисленные белки, которые специфически связываются с этим протеогликаном, а также не менее многочисленные синтетазы, вовлеченные в синтез цепей глюкозаминогликанов и их присоединение к белковой сердцевине. Протеогликаны и соответствующие гены классифицируются согласно их глюкозаминогликанным цепям, и основные типы включают хондроитинсульфат протеогликан (гены CSPG1, CSPG2, CSPG3, CSPG4, CSPG5, CSPG6) и гепарансульфат протеогликан (перлекан, ген HSPG2).

Эти протеогликаны преимущественно вовлечены в образование основной структуры геля. Мутации в хондроитинсульфат протеогликанах могут приводить к скелетной дисплазии ${ }^{2}$ Гепарансульфат протеогликан участвует в клеточной адгезии, обладает ангиогенными свойствами, и генетические дефекты в гене перлекана приводят к хронической миотонии и скелетной дисплазии ${ }^{3}$. Декорин (ген DCN) и люмикан (ген LUM) взаимодействуют с коллагеновыми волокнами и ограничивают диаметр волокон (см. ниже).

\footnotetext{
2 Домницкая Т.М. Клиническое значение применения магния оротата у подростков с синдромом дисплазии соединительной ткани сердца / Т.М. Домницкая, А.В. Дьяченко, О.О. Куприянова, М.В. Домницкий // Кардиология. - 2005. №45 (3). - C. 76.

${ }^{3}$ Gleghorn L., Ramesar R., Beighton P., Wallis G. A mutation in the variable repeat region of the aggrecan gene (AGC1) causes a form of spondyloepiphyseal dysplasia associated with severe, premature osteoarthritis. Am J Hum Genet. 2005; 77(3): 484-90 Epub $2005 \mathrm{Ju}$.
} 
Кератансульфатный протеогликан люмикан встречается в роговице и интерстициальных ВКМ сердца, аорты, скелетной мускулатуры, кожи и межпозвоночных дисков. Трансгенные мыши с дефицитом люмикана демонстрировали уменьшение в жесткости сухожилий, повышенную склонность к вывихам суставов и остеоартрит ${ }^{4}$.

Ферменты, участвующие в биохимических модификациях и присоединении глюкозаминогликанов, могут значительно влиять на структуру внеклеточной матрицы. Например, дефицит ксилозил b-1,4-галактозилтрансферазы 7 (ген B4GALT7) связан с одной из форм синдрома Элерса - Данло (склонность к вывихам, хрупкая или гиперэластичная кожа, хрупкие кровяные сосуды и т. д., номер по ОМIM 130000) 5 .

Многодоменные гликобелки включают фибронектин, ламинины и тенасцины. Данные белки состоят из десятков однородных структурных модулей (доменов), ковалентно связанных друг с другом с образованием цепей. Фибронектин (ген FN1) участвует в адгезии клеток к ВКМ, а также в процессах миграции клеток, заживления ран, свертывания крови и иммунного ответа. Ламинины (гены LAMA1, LAMA2, LAMA3, LAMA4; LAMB1, LAMB2; LAMC1, LAMC2) важны для дифференцирования, адгезии и миграции клеток; генетические дефекты в большинстве ламининов приводят к серьезным формам мускульной дистрофии и булезного эпидермолиза. Тенасцины (TNXB, TNC), вероятно, играют структурную роль, и дефекты в тенасцинах могут проводить к синдрому Элерса - Данло.

Коллагеновые волокна способствуют наличию в соединительной ткани прочности и придают долговечность. Каждое коллагеновое волокно имеет несколько микрометров в диаметре и включает в себя тысячи индивидуальных полипептидных цепей коллагенов, плотно упакованных вместе.

Коллагены являются самыми вместительными по количеству во внеклеточной матрице и в соединительной ткани. В геноме чело-

\footnotetext{
${ }^{4}$ Там же.

${ }^{5}$ Jepsen K.J., Wu F., Peragallo J.H., Paul J., Roberts L., Ezura Y., Oldberg A., Birk D.E., Chakravarti S. A syndrome of joint laxity and impaired tendon integrity in lumican- and fibromodulin-deficient mice. J Biol Chem. 2002; 277(38): 35532-40 Epub 2002.
} 
Глава 1. Теоретические основы оценки течения беременности, исхода родов для матери и плода при недифференцированной дисплазии соединительной ткани

века присутствует примерно 50 генов, кодирующих различные коллагены, и продукты данных генов формируют более чем 20 типов коллагеновых волокон, которые присутствуют во всех типах ткани.

Коллагены можно подразделить в зависимости от положения в ткани и от выполняемой ими функции. Существует четыре основных типа коллагенов (I-IV):

1) коллаген I (гены COL1A1, COL1A2), который входит в состав костей, сухожилий и хрящей, кроме того, его можно обнаружить в шрамах;

2) коллаген II (ген COL2A1) является базовым компонентом хряща;

3) коллаген III (ген COL3A1) образует ретикулярные волокна;

4) коллаген IV (гены COL4A1, COL4A2, COL4A3, COL4A4, COL4A5, COL4A6) образует базальную ламину, на которой держится эпителий.

При определенных мутациях и неправильной выработке того или иного коллагена могут возникнуть коллагеновые болезни.

За синтезом проколлагенов на рибосоме идет гидроксилирование специфических пролинов и лизинов. Эти посттрансляционные модификации основываются на аскорбиновой кислоте и требуются для верной сборки полипептидных цепей коллагена в коллагеновые фибрилы. Гидроксилирование пролинов катализируется пролил-3-гидроксилазой 1 (ген LEPRE1/P3H1), и мутации в данном гене приводят к рецессивному метаболическому расстройству костей ${ }^{6}$. Кроме того, коллагены включают в свой состав гидроксилированные лизины, с которыми ковалентно соединены полисахариды, что необходимо для балансирования структуры.

Полипептидные цепи коллагена самообразуют коллагеновые фибрилы, которые потом преобразуются в коллагеновые волокна. Если присутствуют нарушения в данном самообразовании, то это может привести к болезни Элерса-Данло и другим заболеваниям соединительной ткани человека, что было протестировано на животных.

Затем идет процесс ремоделирования (то есть деградация или протеолиз) коллагеновых волокон ВКМ, который основывается на

\footnotetext{
${ }^{6}$ Rosenbaum K.N., Tifft C.J., Bulas D.I., Kozma C., Smith P.A., Eyre D.R., Marini J.C. Prolyl 3-hydroxylase 1 deficiency causes a recessive metabolic bone disorder resembling lethal/severe osteogenesis imperfecta. Nat Genet. 2007; 39(3): 359-65 Epub 2007 Fe.
} 
матриксных металлопротеиназах (ММП). Геном человека включает в себя не менее 200 ММП-подобных генов, включая собственно ММП (25 генов), мембранно-связанные MMП, ADAM протеиназы (дизинтегрин-металлопротеиназные домены), ADAMTS протеиназы (дизинтегрин-металлопротеиназные домены с тромбоспондиновым мотивом) и ряд других.

Несбалансированный протеолиз компонентов ВКМ, который спровоцирован избыточной активностью ММП, может стать причиной ряда заболеваний, таких как артрит, рак, атеросклероз, аневризмы аорты и фиброз.

Эластиновые волокна ВКМ необходимы для эластичности внеклеточной матрицы и соединительной ткани, базовым элементом которой является эластин. Эластин входит в состав артерии приблизительно на 50\%. Отличительной чертой эластина является то, что он представлен лишь одним геном (ELN на хромосоме 7). Мутации данного гена стимулируют ряд заболеваний аорты, артерий.

Из всего вышеизложенного следует, что нарушения в работе функций белков внеклеточной матрицы могут привести к ряду заболеваний, которые именуются дисплазией соединительной ткани.

О.А. Громова, И.Ю. Торшин в своей статье «Феноменология дисплазий соединительной ткани» рассматривают термин «дисплазия» для обозначения абнормального роста/развития ткани или органа ${ }^{7}$ или дисбаланса коллагенов, нарушения работы клеток соединительной ткани.

Согласно данной статье причинами дисплазии могут являться:

1) абнормальный синтез или сборка коллагена;

2) синтез абнормального коллагена;

3) чрезмерная деградация коллагена;

4) нарушения структуры коллагеновых волокон вследствие недостаточной поперечной сшивки;

5) аналогичные аномалии, связанные с эластиновыми волокнами;

6) разрушение ткани посредством аутоиммунных реакций;

${ }^{7}$ Громова О.А. Феноменология дисплазий соединительной ткани / О.А. Громова, И.Ю. Торшин // Академия эстетической медицины. - 2014 [Электронный ресурс]. - Режим доступа: http://www.tat90.ru/page.xhtml?u=39BBAB366F5E45B4 ACBE5E399CFC2013 
Глава 1. Теоретические основы оценки течения беременности, исхода родов для матери и плода при недифференцированной дисплазии соединительной ткани

7) многие другие, не изученные на сегодняшний момент мехаНизмы.

В связи с наличием большого количества мутагенных воздействий, сложности структуры и функций соединительной ткани дисплазия соединительной ткани может быть как распространенной, так и локальной. Необходимо отметить, что существует и обилие проявлений дисплазии соединительной ткани, она может проявляться в качестве изменений психологического профиля личности, вегетативной дисфункции и синдрома хронической усталости до выраженной миопии, аномалий развития почек, иммунных расстройств и аномалий развития клапанного аппарата сердца, клапанных пролапсов и регургитации. Вследствие чего очень часто врач не может руководствоваться только одним методом исследования. Для выявления дисплазии соединительной ткани необходимо применять комплекс методов исследования.

Дисплазию соединительной ткани можно разделить по общей классификации на дифференцированную и недифференцированную. Дифференцированная дисплазия соединительной ткани выражена генетическим образом, то есть она наследуется, она маркирована четкой клинической картиной, известными генными дефектами и биохимическими нарушениями. К числу таких заболеваний относится синдром Элерса - Данлоса, синдром Марфана, несовершенный остеогенез, мукополисахаридозы, системный эластоз, диспластический сколиоз, синдром Билса (врожденная контрактурная арахнодактилия) и т. д.

Недифференцированная дисплазия соединительной ткани не наследуется, это ряд патологий, чьи фенотипические признаки не соответствуют ни одному из дифференцированных заболеваний.

По степени выраженности можно выделить такие виды, как малые (при наличии 3-х и более фенотипических признаков), изолированные (с локализацией в одном органе) и собственно наследственные заболевания соединительной ткани.

Кроме того, в соответствии с преобладающими диспластическими стигмами выделяют 10 фенотипических вариантов соединительнотканной дисплазии:

1. Марфаноподобная внешность (насчитывает 4 и более фенотипических признака скелетной дисплазии). 
2. Марфаноподобный фенотип (неполный набор признаков синдрома Марфана).

3. MASS-фенотип (поражение аорты, митрального клапана, скелета и кожи).

4. Первичный пролапс митрального клапана (характеризуется ЭхоКГ-признаками митрального пролапса, изменениями со стороны кожи, скелета, суставов).

5. Классический элерсоподобный фенотип (неполный набор признаков синдрома Элерса - Данлоса).

6. Гипермобильный элерсоподобный фенотип (описывается гипермобильностью суставов и сопутствующими осложнениями подвывихами, вывихами, растяжениями, плоскостопием, артралгиями, вовлечением костей и скелета).

7. Гипермобильность суставов доброкачественная (состоит из повышенного объема движений в суставах без заинтересованности костно-скелетной системы и артралгий).

8. Недифференцированная соединительнотканная дисплазия (насчитывает 6 и более диспластических стигм, которых, однако, недостаточно для диагностики дифференцированных синдромов).

9. Повышенная диспластическая стигматизация с преимущественными костно-суставными и скелетными признаками.

10. Повышенная диспластическая стигматизация с преимущественными висцеральными признаками (малыми аномалиями сердца или других внутренних органов).

Таким образом, в данной работе будут рассмотрены именно медико-организационные мероприятия по улучшению качества и эффективности дородовой подготовки беременных женщин с недифференцированной дисплазией соединительной ткани и способы их выявления, то есть тех заболеваний, которые не наследуются.

\section{2. СИМПТОМЫ ДИСПЛАЗИИ СОЕДИНИТЕЛЬНОЙ ТКАНИ}

Внешние (фенотипические) признаки соединительнотканной дисплазии представлены конституциональными особенностями, аномалиями развития костей скелета, кожи и др. Пациенты с дисплазией соединительной ткани имеют астеническую конституцию: высокий рост, узкие плечи, дефицит массы тела. Нарушения развития осевого скелета могут быть представлены сколиозом, кифозом, 
Глава 1. Теоретические основы оценки течения беременности, исхода родов для матери и плода при недифференцированной дисплазии соединительной ткани

воронкообразной или килевидной деформациями грудной клетки, ювенильным остеохондрозом. Краниоцефальные стигмы соединительнотканной дисплазии нередко включают долихоцефалию, нарушения прикуса, аномалии зубов, готическое небо, несращение верхней губы и нёба. Патология костно-суставной системы характеризуется О-образной или Х-образной деформацией конечностей, синдактилией, арахнодактилией, гипермобильностью суставов, плоскостопием, склонностью к привычным вывихам и подвывихам, переломам костей.

Со стороны кожных покровов отмечается повышенная растяжимость (гиперэластичность) или, напротив, хрупкость и сухость кожи. Нередко на ней без видимых причин возникают стрии, пигментные пятна либо очаги депигментации, сосудистые дефекты (телеангиэктазии, гемангиомы). Слабость мышечной системы при соединительнотканной дисплазии обусловливает склонность к опущению и выпадению внутренних органов, грыжам, мышечной кривошее. Из других внешних признаков соединительнотканной дисплазии могут встречаться такие микроаномалии, как гипо- или гипертелоризм, лопоухость, асимметрия ушей, низкая линия роста волос на лбу и шее и др.

Висцеральные поражения протекают с заинтересованностью ЦНС и вегетативной нервной системы, различных внутренних органов. Неврологические нарушения, сопутствующие соединительнотканной дисплазии, характеризуются вегетососудистой дистонией, астенией, энурезом, хронической мигренью, нарушением речи, высокой тревожностью и эмоциональной неустойчивостью. Синдром соединительнотканной дисплазии сердца может включать в себя пролапс митрального клапана, открытое овальное окно, гипоплазию аорты и легочного ствола, удлинение и избыточную подвижность хорд, аневризмы коронарных артерий или межпредсердной перегородки. Следствием слабости стенок венозных сосудов служит развитие варикозного расширения вен нижних конечностей и малого таза, геморрой, варикоцеле. Пациенты с соединительнотканной дисплазией имеют склонность к возникновению артериальной гипотензии, аритмий, атриовентрикулярных и внутрижелудочковых блокад, кардиалгий, внезапной смерти.

Кардиальным проявлениям нередко сопутствует бронхолегочный синдром, характеризующийся наличием кистозной гипопла- 
зии легких, бронхоэктазов, буллезной эмфиземы, повторных спонтанных пневмотораксов. Характерно поражение ЖКТ в виде опущения внутренних органов, дивертикулов пищевода, гастроэзофагеального рефлюкса, грыжи пищеводного отверстия диафрагмы. Типичными проявлениями патологии органа зрения при соединительнотканной дисплазии служат близорукость, астигматизм, дальнозоркость, нистагм, косоглазие, вывих и подвывих хрусталика.

Co стороны мочевыделительной системы может отмечаться нефроптоз, недержание мочи, почечные аномалии (гипоплазия, удвоение, подковообразная почка) и пр. Репродуктивные нарушения, ассоциированные с соединительнотканной дисплазией, у женщин могут быть представлены опущением матки и влагалища, метро- и меноррагией, самопроизвольными абортами, послеродовыми кровотечениями; у мужчин возможен крипторхизм. Лица, имеющие признаки соединительнотканной дисплазии, склонны к частым ОРВИ, аллергическим реакциям, геморрагическому синдрому.

Заболевания из группы соединительнотканных дисплазий не всегда диагностируются правильно и своевременно. Часто больные с теми или иными признаками дисплазии наблюдаются у врачей разных специальностей: травматологов, неврологов, кардиологов, пульмонологов, нефрологов, гастроэнтерологов, офтальмологов и др. Распознавание недифференцированных форм соединительнотканной дисплазии усложняется отсутствием единых алгоритмов диагностики. Наибольшей диагностической значимостью обладает выявление совокупности фенотипических и висцеральных признаков. С целью обнаружения последних широко применяются ультразвуковые (ЭхоКГ, УЗИ почек, УЗИ органов брюшной полости), эндоскопические (ФГДС), электрофизиологические (ЭКГ, ЭЭГ), рентгенологические (рентгенография легких, суставов, позвоночника и др.) методы. Выявление характерных полиорганных нарушений, главным образом со стороны опорно-двигательной, нервной и сердечно-сосудистой систем, с высокой степенью вероятности свидетельствует о наличии соединительнотканной дисплазии.

Дополнительно исследуются биохимические показатели крови, система гемостаза, иммунный статус, проводится биопсия кожи. В качестве метода скрининг-диагностики соединительнотканной дисплазии предложено проводить исследование папиллярного рисунка кожи 
Глава 1. Теоретические основы оценки течения беременности, исхода родов для матери и плода при недифференцированной дисплазии соединительной ткани

передней брюшной стенки: выявление неоформленного типа папиллярного рисунка служит маркером диспластических нарушений. Семьям, где имеются случаи соединительнотканной дисплазии, рекомендуется пройти медико-генетическое консультирование.

Прогноз соединительнотканной дисплазии во многом зависит от степени выраженности диспластических нарушений. У пациентов с изолированными формами качество жизни может не нарушаться. У больных с полисистемным поражением повышен риск ранней и тяжелой инвалидизации, преждевременной смерти, причинами которой могут выступать фибрилляция желудочков, ТЭЛА, разрыв аневризмы аорты, геморрагический инсульт, тяжелые внутренние кровотечения.

\section{3. ДИСПЛАЗИЯ СОЕДИНИТЕЛЬНОЙ ТКАНИ И БЕРЕМЕННОСТЬ}

Дисплазия соединительной ткани включается в группу генетических гетерогенных и клинически полиморфных патологий, которым свойственна общность нарушения формирования и функционирования соединительной ткани в эмбриональном и постнатальном периоде. Как уже отмечалось ранее, существует генетическая неоднородность данной патологии, поэтому можно выделить большой спектр ее клинических вариантов, например, от синдромов (Марфана, Элерса Данлоса) до множества недифференцированных (несиндромных) форм с мультифакториальными механизмами развития.

В меньшей степени изучена и освещена в научной литературе такая проблема, как дисплазия соединительной ткани и беременность. Генерализованный характер поражения соединительной ткани с вовлечением в патологический процесс репродуктивной системы имеет последствия, которые проявляются на течении беременности и родов. Затем все вызванные изменения, происходящие вследствие наличия дисплазии соединительной ткани, дают толчок к декомпенсации клинически явных или латентных проявлений врожденной «слабости» соединительной ткани. Кроме того, наиболее опасными заболеваниями из всей группы дисплазии соединительной ткани могут по праву называться синдромы Марфана, Элерса - Данлоса и недифференцированной дисплазии соединительной ткани. Они требуют детального наблюдения в ходе 
беременности и принятия определенных мер. Рассмотрим каждый из них последовательно.

Синдромом Марфана (CM) является наследственное нарушение обмена соединительной ткани с аутосомно-доминантным типом наследования и популяционной частотой 1:10000 - 1:15000. Он базируется на мутации в гене белка фибриллина (FBN1) или а2-цепи коллагена I типа. В типичном случае CM - это сочетание характерных изменений опорно-двигательного аппарата, сердечно-сосудистой системы и глаз. Благодаря современному консервативному и хирургическому ведению больных с СМ всё больше пациенток достигают репродуктивного возраста, и продолжительность жизни увеличилась в среднем на 13 лет. При беременности у женщин с СМ может возникнуть одна из двух проблем: вероятность расслоения и разрыва аорты и риск иметь больного ребенка, обе из которых требуют определенного объяснения врача-гинеколога своей пациентке . $^{8}$

Обычно прогноз больных с СМ характеризуется степенью поражения сердечно-сосудистой системы. Типично прогрессирующее расширение восходящего отдела аорты с формированием недостаточности аортального клапана и/или расслоением и разрывом стенки сформировавшейся аневризмы. В большей степени значение имеет риск расслоения аорты у женщин, имевших расширение корня аорты до беременности. Такие исследователи, как J. Kudlicki, J. Drozd, J. Oleszczuk, полагают, что беременность может вызвать значительные ухудшения в состоянии женщины и быть противопоказанной, если диаметр основания аорты превышает 4 см9. Относительно безопасной и допустимой считается беременность при отсутствии существенного поражения сердца и магистральных сосудов. При бдительном контроле за состоянием женщин с СМ при минимальных изменениях сердечно-сосудистой системы и диаметром корня аорты менее 4 см не было зарегистрировано значительной дилатации корня аорты ни в период беременности, ни при длительном наблюдении в дальнейшем. Но необходимо отметить, что

${ }^{8}$ Elkayam U., Ostrzega E., Shotan A., Mehra A. Cardiovascular problems in pregnant women with the Marfan syndrome. Ann Intern Med 1995; 123 (2): 117-122.

${ }^{9}$ Kudlicki J., Drozd J., Oleszczuk J. Pregnancy in women with Marfan's syndrome. Ginekol Pol 1997; 68 (2): 94-101. 
Глава 1. Теоретические основы оценки течения беременности, исхода родов для матери и плода при недифференцированной дисплазии соединительной ткани

неблагоприятный исход может быть вызван и при отсутствии расширения корня аорты.

Риск дилатации и расслоения аорты достигает максимума в третьем триместре беременности и во время родов, в связи с этим контроль за состоянием сердца и аорты должен быть динамическим. Наиболее доступным диагностическим методом является эхокардиография, но она может стать недостаточно информативной при визуализации надклапанной части восходящего отдела аорты. Измерение диаметра аорты и оценка функции аортального клапана должны производиться ежемесячно в течение первых 6 месяцев беременности, далее - дважды в месяц. J. Kudlicki в своей работе отмечает необходимость дальнейшего тщательного наблюдения за состоянием сердечно-сосудистой системы еще и в течение двух месяцев после родов ${ }^{10}$.

Расширение восходящего отдела аорты, отмеченное у женщин с СМ во время беременности, является предиктором ее расслоения. При увеличении диаметра корня аорты более 5,5 см (оно является критическим) необходимо кардиохирургическое вмешательство ${ }^{11}$. Оно может быть выполнено параллельно или непосредственно после кесарева сечения, в работах T. Uchida, H. Ogino приведено немало случаев успешного исхода подобного комбинированного лечения для матери и плода ${ }^{12}$.

Ввиду высокой угрозы расслоения и разрыва аорты при наблюдении беременных с СМ огромное значение имеет адекватный контроль над параметрами АД. Рекомендуемый уровень систолического АД не должен превышать 130 мм рт. ст. Особые показания в связи с этим приобретают b-адреноблокаторы. В настоящее время доказана клиническая эффективность их длительного профилактического применения в предупреждении расширения и расслоения аорты.

Решение о выборе способа принятия родов у женщин с СМ принимается дифференцировано с учетом общих и акушерских показаний. В качестве анестезиологического пособия предпочитают

\footnotetext{
10 Там же.

${ }^{11}$ Aubard Y., Lagarde M., Villate D., Granjean M.H. Marfan's syndrome and pregnancy. A case report and review of the literature. J Gynecol Obstet Biol Reprod 1995; 24 (4): 426-433.

${ }^{12}$ Uchida T., Ogino H., Ando M. et al. Aortic dissection in pregnant woman with the Marfan syndrome. Kyobu Geka 2002; 55 (8 Suppl): 693-696.
} 
эпидуральную анестезию из-за меньшего по сравнению с наркозом риска гемодинамических расстройств.

К числу акушерских осложнений относят самопроизвольный выкидыш и преждевременные роды, маточное кровотечение, слабость родовой деятельности. Однако в целом частота акушерских осложнений у женщин с СМ, согласно статистике, не более, чем в общей популяции. Так, по данным K.J. Lipscomb, беременность без осложнений у женщин с СМ имела место у 30 из 36 женщин с $\mathrm{CM}^{13}$, a, по наблюдениям J. Lind и H.C. Wallenburg, течение беременности и неонатальные исходы у пациенток с СМ не отличались при сопоставлении со здоровыми матерями ${ }^{14}$.

Основной проблемой для женщин с СМ является высокий генетический риск для потомства. Аутосомно-доминантный тип наследования характеризуется вероятностью рождения больного ребенка, тождественной 50\%. Расшифровка генных дефектов, отвечающих за возникновение СМ, дает основания проводить перинатальную и преимплантационную диагностику, - все это необходимо, чтобы избежать рождения больного ребенка. Особые диагностические проблемы создают спорадические случаи заболевания, частота которых составляет около $30 \%$ от общего количества больных с $\mathrm{CM}^{15}$.

Так, риск сердечно-сосудистых осложнений, связанных с беременностью и родами, и высокая вероятность рождения больного потомства требуют обстоятельного информирования женщины с $\mathrm{CM}$, желающей иметь ребенка, о возможных последствиях. Обязателен предварительный и текущий медицинский контроль с оценкой диаметра корня аорты, а также состояния аортального клапана. При ведении беременности и родов должна быть предусмотрена возможность экстренной кардиохирургической операции.

Синдром Элерса - Данлоса (СЭД) в отличие от СМ характеризуется большим генетическим и клиническим разнообразием и вклю-

${ }^{13}$ Lipscomb K.J., Smith J.C., Clarke B. et al. Outcome of pregnancy in women with Marfan's syndrome. Br J Obstet Gynaecol 1997; 104 (2): 201-206.

${ }^{14}$ Lind J., Wallenburg H.C. The Marfan syndrome and pregnancy: a retrospective study in a Dutch population. Eur J Obstet Gynecol Reprod Biol 2001; 98 (1): 28-35.

${ }^{15}$ Okamoto M., Hayatsu K., Tomita M., Shimoji K. Continuous epidural analgesia with intensive monitoring of cardiovascular system for vaginal delivery in a patient with Marfan's syndrome. Masui 2002; 51 (8): 916-920. 
Глава 1. Теоретические основы оценки течения беременности, исхода родов для матери и плода при недифференцированной дисплазии соединительной ткани

чает в себя разный тип наследования (аутосомно-доминантный, аутосомно-рецессивный, Х-сцепленный). Тяжелые формы болезни встречаются редко - 1:100000, легкие, нераспознанные намного чаще 1:5000. К симптомам СЭД относят следующие признаки: геморрагический синдром, повышенная эластичность кожи и гипермобильность суставов. В редких случаях могут наблюдаться повреждения глаз, желудочно-кишечного тракта, сердечно-сосудистой системы, опорнодвигательного аппарата, разнообразная патология гениталий.

В одной из известных работ Y. Sorokin можно найти статистическую информацию об исходах 138 беременностей у 43 женщин с СЭД, которая включает в себя сведения о частоте акушерских и гинекологических осложнений при данной патологии ${ }^{16}$. У женщин с СЭД 3,15\% беременностей закончились мертворождением, встречалось кровотечение при родах $(4,7 \%)$; были преждевременные роды $(23,1 \%)$, самопроизвольные выкидыши (28,9\%). В похожем по масштабу наблюдении (128 беременностей у 46 женщин) J. Lind и H.C. Wallenburg обнаружили распространенность послеродовых кровотечений и разрывов промежности, однако статистически не обосновали выводы о повышенной частоте преждевременных родов и сделали вывод о благоприятных в целом материнских и неонатальных результатах беременности у женщин с СЭД ${ }^{17}$. Однако при анализе исходов беременности и родов у женщин с отдельными типами СЭД выводы оказались не столь однозначными.

На данный момент выделяются 11 типов СЭД, их клинические проявления частично совпадают и накладываются друг на друга. Наиболее распространенными являются I, II и III типы, к наиболее тяжелым относятся I тип, протекающий со скелетными деформациями, варикозным расширением вен и пороками сердца, IV тип, со свойственными ему аневризмами и спонтанными разрывами артерий, и VI тип со злокачественной патологией глаз.

Чаще всего неблагоприятные материнские исходы наступают при IV - сосудистом - типе СЭД. Данный вариант болезни является

\footnotetext{
${ }^{16}$ Sorokin Y., Johnson M.P., Rogowski N. et al. Obstetric and gynecologic dysfunction in the Ehlers-Danlos syndrome. J Reprod Med 1994; 39 (4): 281-284.

${ }^{17}$ Lind J., Wallenburg H.C. Pregnancy and the Ehlers-Danlos syndrome: a retrospective study in a Dutch population. Acta Obstet Gynecol Scand 2002; 81 (4): 293-300.
} 
следствием мутации гена COL3A1, контролирующего синтез коллагена III типа. Беременность при данном типе СЭД связана с огромным риском для женщин, так как при статистическом материнская смертность у женщин с данным типом СЭД происходит в $25 \%$ случаев из $100 \%{ }^{18}$.

По данным М. Реріn, осложнения беременности привели к смерти 12 из 81 женщины, страдающей IV типом СЭД ${ }^{19}$. Большинство смертельных случаев связано со спонтанным разрывом артерий, матки или кишечника. У пациенток с IV типом СЭД во время беременности могут присутствовать случаи разрыва матки в сочетании с некрозом кишечника, расслоения коронарной артерии с развитием инфаркта миокарда, разрыва аорты, подвздошной артерии и тощей кишки, расслоения аорты, наблюдались случаи задержки роста плода.

При наличии других типов СЭД течение и исход беременности являются более благоприятными. Тем не менее, при III - «гипермобильном» - типе СЭД описаны случаи преждевременного разрыва плодных оболочек, неправильного предлежания плода и низкого веса при рождении. Похожие осложнения описаны и при относительно благоприятном II типе СЭД.

Таким образом, при планировании и ведении беременности у пациенток с СЭД необходимо учитывать, какой вариант болезни они имеют, и быть готовым к потенциальным осложнениям. Для снижения риска разрыва тазовых и промежностных сосудов во время родов необходимо проводить кесарево сечение. Повышенная ранимость кожи и сосудов, а также склонность к кровотечениям часто приводят к наличию дополнительных проблем при выполнении оперативных вмешательств или проведении эпидуральной анестезии. В случае преждевременной родовой деятельности необходимо избегать токолизиса с применением адреномиметиков из-за их влияния на общую гемодинамику.

\footnotetext{
${ }^{18}$ Brees C.K., Gall S.A. Rupture of the external iliac artery during pregnancy: a case of type IV Ehlers-Danlos syndrome. J Ky Med Assoc 1995; 93 (12): 553-555.

${ }^{19}$ Pepin M., Schwarze U., Superti-Furga A., Byers P.H. Clinical and genetic features of Ehlers-Danlos syndrome type IV, the vascular type. N Engl J Med 2000; 342 (10): 673-680. 
Глава 1. Теоретические основы оценки течения беременности, исхода родов для матери и плода при недифференцированной дисплазии соединительной ткани

\section{4. НЕДИФФЕРЕНЦИРОВАННАЯ ДИСПЛАЗИЯ СОЕДИНИТЕЛЬНОЙ ТКАНИ КАК ПАТОЛОГИЯ В ГИНЕКОЛОГИИ И АКУШЕРСТВЕ}

Как уже отмечалось ранее, к числу наиболее опасных заболеваний у женщин относится недифференцированная дисплазия соединительной ткани, что, в свою очередь, приводит к необходимости ее изучения.

Ее клинические проявления нельзя соотнести ни с одной из известных наследственных болезней, но они могут косвенно с ними совпадать или их напоминать (морфано- или элерсоподобный фенотип). Наиболее изученным и распространенным проявлением недифференцированной дисплазии соединительной ткани является пролапс митрального клапана (ПМК). ПМК является самой частой клапанной аномалией у лиц молодого возраста, в т.ч. женщин репродуктивного периода.

По данным Y.T. Chia, доля ПМК в структуре врожденных заболеваний сердца у беременных равняется $60,8 \%{ }^{20}$.

Как правило, ПМК имеет малосимптомное течение и благоприятный прогноз, но в ряде случаев он оказывается сопряженным с серьезными осложнениями, к которым относят нарушения сердечного ритма, недостаточность кровообращения, тромбоэмболии, присоединение инфекционного эндокардита, а также внезапная смерть. Увеличение сердечного выброса, объема циркулирующей крови и внеклеточной жидкости, закономерно развивающихся во время беременности, создают дополнительные нагрузку на сердечно-сосудистую систему и способствуют нарастанию частоты указанных осложнений. В частности, у женщин с ПМК при беременности нередко присутствуют сердечная недостаточность и аритмии, зафиксированы случаи отека легких и нарушений сердечного ритма, в т.ч. потенциально опасных.

Огромную проблему представляет вторичный инфекционный эндокардит, примеры его возникновения у женщин с ПМК в период беременности или после родов приведены во многих работах. Повышенная вероятность развития инфекционного эндокардита

\footnotetext{
${ }^{20}$ Chia Y.T., Yeoh S.C., Viegas O.A. et al. Maternal congenital heart disease and pregnancy outcome. J Obstet Gynaecol Res 1996; 22 (2): 185-191.
} 
оправдывает профилактическое применение антибиотиков в перинатальном периоде у женщин с ПМК. И беременность, и ПМК относятся к факторам риска тромбоэмболических осложнений. Причинами тромбов являются миксоматозно измененные створки митрального клапана; типичные для дисплазии соединительной ткани нарушения агрегационной функции тромбоцитов также являются предпосылками к тромбообразованию. Серьезную угрозу для жизни представляют тромбоэмболии сосудов головного мозга ${ }^{21}$.

Как правило, тяжелые осложнения наблюдаются у пациенток с гемодинамически значимой митральной регургитацией и явной миксоматозной дегенерацией клапанных створок. В отсутствии миксоматозной дегенерации и выраженных нарушений внутрисердечной гемодинамики исход беременности для женщин с ПМК благоприятен.

Менее изученным и противоречивым является вопрос об особенностях течения беременности и родов у женщин с ПМК. Согласно работе И.В. Елисеевой частота осложнений родов и послеродового периода у женщин с ПМК оказалась в 3 раза выше, чем у соматически здоровых ${ }^{22}$. В числе осложнений преждевременные роды, аномалии родовой деятельности, больший процент рождения недоношенных детей. N. Jana описывает случаи самопроизвольных абортов, преждевременных родов и внутриутробной гибели плода ${ }^{23}$, а Y.T. Chiа указывает на повышенную потребность в стимуляции родовой деятельности ${ }^{24}$.

Однако многими исследователями не было зарегистрировано существенного увеличения числа акушерских осложнений у женщин с ПМК в сравнении со здоровыми.

Итак, беременные с ПМК, по всей вероятности, могут быть отнесены к группе риска по акушерской и перинатальной патологии,

${ }^{21}$ De Vos M., Nuytinck L., Verellen C., De Paepe A. Preterm premature rupture of membranes in a patient with the hypermobility type of the Ehlers-Danlos syndrome. A case report. Fetal Diagn Ther 1999; 14 (4): 244-247.

22 Елисеева И.В. Клинико-функциональные особенности соматического состояния и течения родов у женщин с пролапсом митрального клапана // Клин мед. 2003. - №81 (3). - C. 22-24.

${ }^{23}$ Jana N., Vasishta K., Khunnu B. Pregnancy in association with mitral valve prolapse. Asia Oceania J Obstet Gynaecol 1993; 19 (1): 61-65.

${ }^{24}$ Chia Y.T., Yeoh S.C., Lim M.C. Pregnancy outcome and mitral valve prolapse. Asia Oceania J Obstet Gynaecol 1994; 20 (4): 383-388. 
Глава 1. Теоретические основы оценки течения беременности, исхода родов для матери и плода при недифференцированной дисплазии соединительной ткани

а при наличии миксоматозной дегенерации и значимой (превышающей II степень) митральной регургитации - еще и к группе риска по неблагоприятным материнским исходам. Известность в популяции и тяжесть возможных осложнений ПМК еще раз подчеркивает важность всеобщего обследования беременных с обязательным применением эхокардиографии.

Основным типом акушерской патологии является самопроизвольный аборт, угроза его наступления в качестве выкидыша может прослеживаться до 22 недель, а в срок с 28 по 37 неделю данная патология приводит к преждевременным родам, но только в том случае, если ребенок выжил после родов, иначе это считается поздним выкидышем.

С угрозой невынашивания плода связана еще и такая патология, как плацентарная недостаточность, и ряд других патологий гипоксического генезиса. Необходимо отметить, что наличие патологий гипоксического генезиса непосредственно оказывает влияние на плод и его развитие. При наличии невынашивания смешанного генеза у плода проявляются негативные последствия на неврологическом уровне, что может проявляться в наличии мозговых дисфункций (инсомния, невротическая депрессия).

Отметим, что причинами плацентарной недостаточности может быть и наличие синдрома недифференцированной дисплазии соединительной ткани. В свою очередь, наличие плацентарной недостаточности может привести к вегетативной дисфункции. При этом отмечается понижение эффективности регуляторных влияний со стороны легочной, сосудистой и нейрогуморальной систем, что непосредственно оказывает влияние на ритм сердца. Может наблюдаться уменьшение потенциала вегетативной нервной системы и увеличение работы симпатического отдела, понижение антистрессовой устойчивости, из-за чего у матери и плода можно наблюдать стрессовое состояние. Вследствие этого происходит общее снижение уровня адаптационно-компенсаторных возможностей организма, в большей степени это проявляется у плода. При таких нарушениях плоду сложно применять свои защитно-приспособительные возможности, поэтому состояние временной гипоксии при родах будет более губительным для здоровья.

В условиях отсутствия настоящих возможностей генной терапии наследственных заболеваний активно обсуждается вопрос о 
патогенетическом лечении дисплазии соединительной ткани. Аналогичное лечение, направленное на коррекцию нарушенного метаболизма коллагена, выступает важным фактором профилактики вероятных осложнений указанной патологии. Отдельное значение в связи с этим приобретают препараты магния.

Ионы магния входят в состав основного вещества соединительной ткани и участвуют в регуляции ее метаболизма. В условиях магниевой недостаточности нарушается способность фибробластов продуцировать коллаген. Подтвержден дефицит магния при ПМК, на практике отмечена эффективность препаратов магния при данной патологии. Также в работе А.И. Мартынова показана принципиальная возможность редукции главных клинико-функциональных проявлений ПМК под влиянием курса лечения магниевой солью оротовой кислоты (препарат «Магнерот», фирма «Верваг фарма») $)^{25}$.

С другой стороны, недостаток магния сопряжен с широким спектром осложнений беременности и родов. Доказано, что снижение содержания магния приводит к повышению тонуса миометрия и лежит в основе преждевременной родовой деятельности. Низкий уровень внутриклеточного магния способствует развитию артериальной гипертонии беременных. Дефицит магния при беременности может являться причиной задержки внутриутробного развития плода и ухудшения выживаемости потомства.

Так, заместительная терапия препаратами магния может явиться значимой мерой предупреждения осложнений дисплазии соединительной ткани в период беременности и возможных осложнений беременности и родов у женщин с данной патологией. Действенность данного лечения беременных с врожденной неполноценностью соединительной ткани нуждается в дополнительном уточнении.

\footnotetext{
${ }^{25}$ Мартынов А.И. Новые подходы к лечению больных с идиопатическим пролабированием митрального клапана / А.И. Мартынов, О.Б. Степура, А.Б. Шехтер [и др.] // Тер архив. - 2000. - №72 (9). - С. 67-70. 


\section{ГЛАВА 2. МЕТОДЫ ИССЛЕДОВАНИЯ ТЕЧЕНИЯ БЕРЕМЕННОСТИ У ЖЕНЩИН, СВЯЗАННЫЕ С НЕДИФФЕРЕНЦИРОВАННОЙ ДИСПЛАЗИЕЙ СОЕДИНИТЕЛЬНОЙ ТКАНИ}

\section{1. ИССЛЕДОВАНИЕ ФЕНОТИПИЧЕСКИХ ПРИЗНАКОВ НЕДИФФЕРЕНЦИРОВАННОЙ ДИСПЛАЗИИ СОЕДИНИТЕЛЬНОЙ ТКАНИ}

При исследовании внешних фенотипических признаков недифференцированной дисплазии соединительной ткани руководствовались фенотипической картой М.Дж. Глесби (1989), которая была модифицирована А.И. Мартыновым в 1996. Данная карта включает в себя следующие фенотипические признаки НДСТ:

1. Долихостеномелия, для нахождения которой используется индекс соотношения рук и роста, который должен быть более 7,6 см.

2. Наличие воронкообразной грудной клетки 1-2 степени. Она чаще проявляется у мужчин, чем у женщин. Характеризуется наличием углубления по средней линии грудины на 0,3-0,5 см и 0,50,7 см, грудной клеткой с килевидным выпячиванием грудины; крыловидными лопатками, которые проявляются в том, что края лопаток выпирают от общей линии спины ровно для того, что становится возможным просунуть кончики пальцев под них; арахнодактилией, то есть наличием длинной и узкой ладони и длинных пальцев (для ее определения проводится тест большого пальца при наличии арахнолактилии дистальные фаланги большого пальца смещены за ульнарный край ладони и тест запястья, то есть дистальные фаланги 1 и 5 пальцев должны частично перекрещиваться при обхвате запястья противоположной руки).

3. Патология позвоночника, которая определяется при клиническом обследовании непосредственно, к ним относятся сколиоз, гиперлордоз поясничного отдела, который проявляется в искривлении позвоночника кпереди с превышением допустимой физиологией нормы.

4. Гипермобильность суставов является характерным признаком недифференцированной дисплазии соединительной ткани как у детей, так и у взрослых. Однако частота наличия данного признака повышается в зависимости от проявления других признаков ДСТ, но она является раз- 
личной в разных популяциях. В меньшей степени она прослеживается у европейцев, в большей степени - у индейцев. Наибольшая подвижность суставов проявляется у детей в возрасте 13-14 лет; к 25-30 годам она снижается в 3-5 раз. Однако гипермобильность суставов характерна именно для подросткового возраста, так как в данный период наблюдается самое высокое количество эластина, вследствие чего происходит увеличение удельного веса эластических волокон. Гипермобильность суставов может снижаться со временем. Если у человека присутствует гипермобильный синдром во второй половине жизни, то он стимулирует развитие разнообразных поражений околосуставных мягких тканей, что, в свою очередь, объясняется тем, что на уже имеющийся дефект СТ более легко накладываются инволютивные процессы в сухожильно-связочном аппарате ${ }^{26}$. Для выявления гипермобильности суставов проводится тщательное обследование и прохождение тестов, таких как пассивное приведение большого пальца через сторону до соприкосновения с предплечьем, перерасгибание в суставах пальцев, перерасгибание мизинца до 90 градусов и т. д.

Необходимо отметить, что гипермобильность 1-го плюснефалангового сустава может привести к развитию одного из основных клинических признаков поперечного плоскостопия.

Все критерии синдрома гипермобильности суставов подразделяются на большие и малые, которые представлены в таблице 1.

Таблица 1

\begin{tabular}{|l|l|}
\hline \multicolumn{1}{|c|}{ Большие критерии } & \multicolumn{1}{|c|}{ Малые критерии } \\
\hline $\begin{array}{l}\text { Счет по шкале Бейтона, должно } \\
\text { быть } 4 \text { или более баллов }\end{array}$ & $\begin{array}{l}\text { Счет по шкале Бейтона, должно быть } \\
1-3 \text { балла }\end{array}$ \\
\hline $\begin{array}{l}\text { Артралгия должна прояв- } \\
\text { ляться более } 3 \text { месяцев в че- } \\
\text { тырех или более суставах }\end{array}$ & $\begin{array}{l}\text { Артралгия должна проявляться в одном- } \\
\text { трех суставах, может встречаться люм- } \\
\text { балгия, спондилез, спондилолиз, спонди- } \\
\text { лолистез }\end{array}$ \\
\hline & $\begin{array}{l}\text { Вывих или подвывих в одном и более } \\
\text { суставе, в крайнем случае может прояв- } \\
\text { ляться вывихом только в одном суставе }\end{array}$ \\
\hline
\end{tabular}

${ }^{26}$ Нечаева Г.И. Диагностика дисплазии соединительной ткани у лиц среднего и пожилого возраста в практике семейного врача / Г.И. Нечаева, И.А. Викторова, И.Ю. Калинина // Рос. сем. врач. - 2004. - №2 (8). - С. 47-54. 
Глава 2. Методы исследования течения беременности у женщин, связанные с недифференцированной дисплазией соединительной ткани

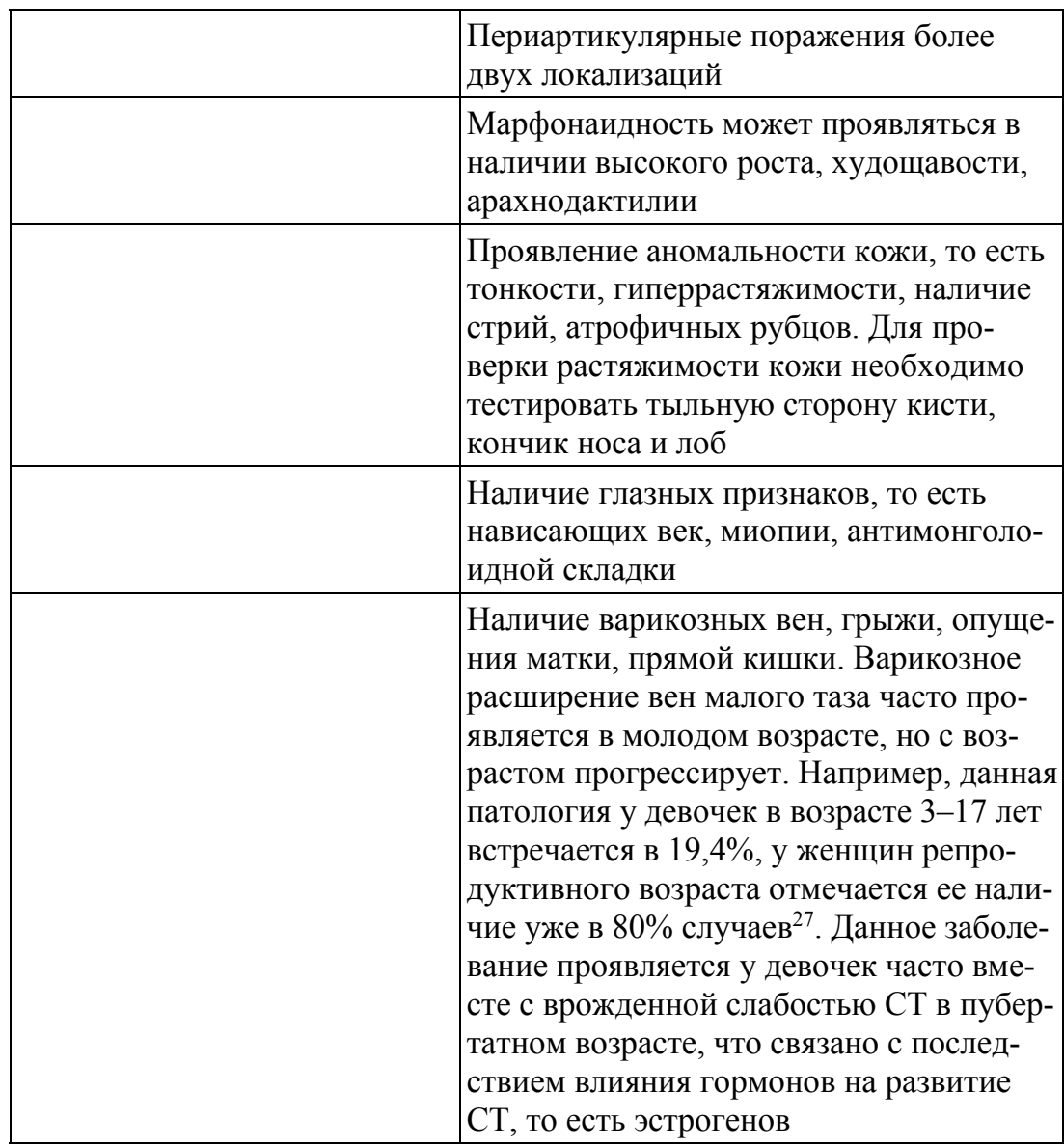

Для того чтобы поставить диагноз недифференцированной дисплазии соединительной ткани с гипермобильностью суставов, необходимо наличие сочетания двух больших и двух малых либо одного большого и четырех малых критериев.

Все аномалии массы тела определяются благодаря индексу Кетле, который находится по формуле: масса тела (кг)/рост(м) ${ }^{2}$, а чтобы проверить, присутствует ли у женщины дефицит массы тела,

27 Адамян Л.В. Диагностика и тактика ведения больных с дисплазией соединительной ткани в акушерстве и гинекологии / Л.В. Адамян, Т.Ю. Смольнова // РМЖ. - 2010. - №6. - C. 41-46. 
необходимо рассчитать индекс Варги, который находится по формуле: (масса тела (кг)/рост(м) $)^{2}-($ возраст/100). Если индекс равен от 1,7 до 1,5, то уменьшение массы тела является умеренным, если менее 1,5 , то повышенное снижение.

Все аномалии работы зрения, такие как миопия, астигматизм, дистопия и т. д., определялись посредством осмотра окулистом и проведения соответствующего опроса. Информацию обо всех варикозных расширениях вен исследовали посредством осмотра пациенток и использования результатов флебографии.

Однако при проведении данного исследования использовался еще ряд методов, таких как эхокардиография.

\section{2. ЭХОКАРДИОГРАФИЯ}

Существенными при определении недифференцированной дисплазии соединительной ткани посредством эхокардиографии являются следующие режимы:

1. М-режим. Он предназначен для предоставления графического изображения вибраций стенок сердца и створок клапана в дихотомическом режиме. Данный режим необходим при оценке размеров сердца и систолической функции желудочков в реальном времени (рис. 1).

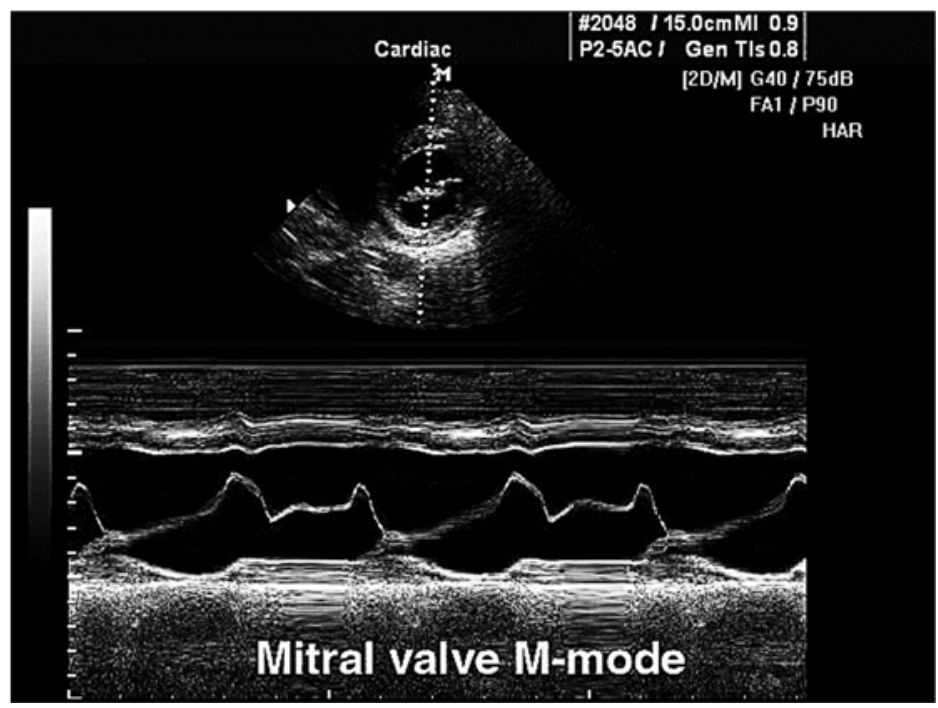

Рисунок 1 
2. В-режим представляет из себя двухмерную эхокардиографию. Позволяет получить изображение сердца по длинной и короткой оси в реальном времени. Он необходим при оценке размеров полостей сердца, толщины стенок желудочков, состояния клапанного аппарата, глобальной и локальной сократимости желудочков, наличии тромбоза полостей и т. п. (рис. 2).

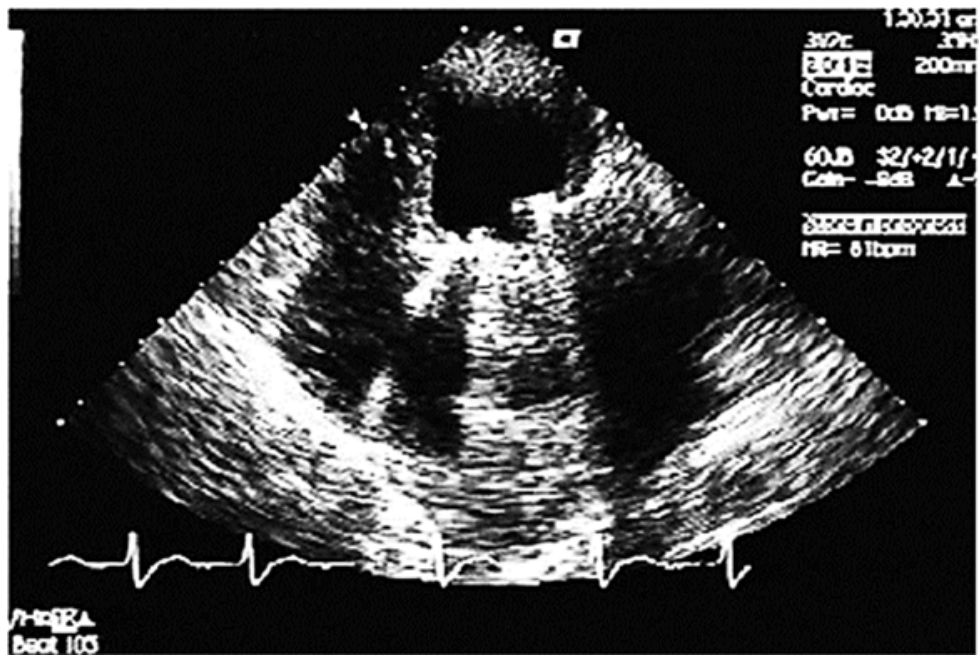

Рисунок 2. Эхокардиография. В-режим. Апикальная четырехкамерная позиция. Нормально функционирующий механический двустворчатый протез митрального клапана, атриомегалия. Акустическая тень от протеза в левом предсердии

3. Доплер-эхокардиография, которая может быть импульсной, цветной, нервно-волновой. Она необходима для исследований направления кровотока, измерения его скоростных характеристик и т. д. (рис. 3). 


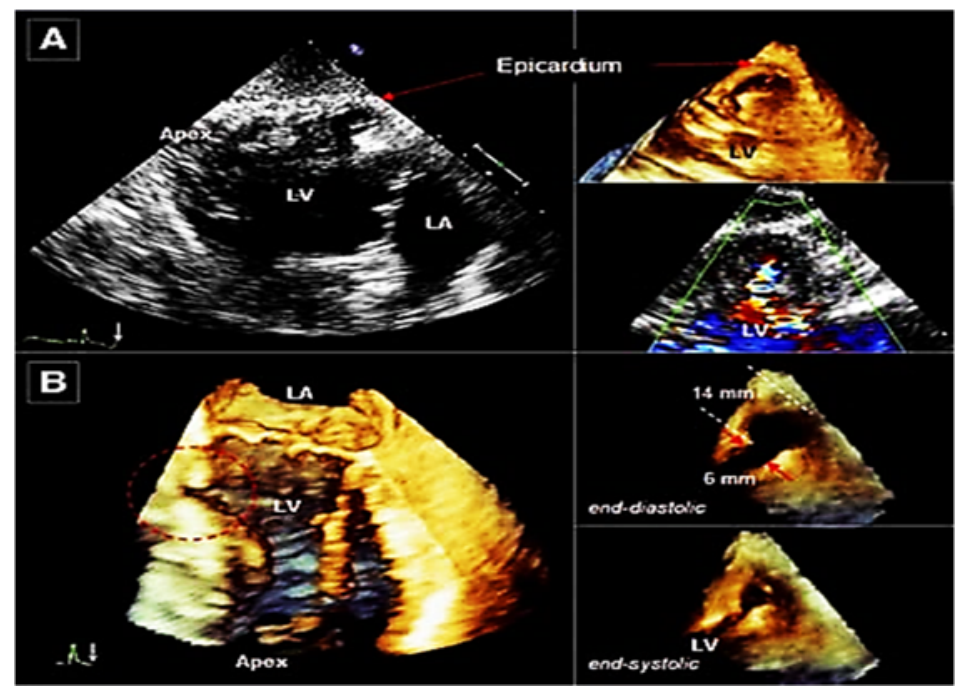

Рисунок 3

При проведении исследования выявлялись структурные и другие характеристики работы сердца, к числу которых относят наличие и количество аномально расположенных хорд, пролапсы клапанов. Доплер-эхокардиография была необходима для анализа работы четырех клапанов, то есть митрального, трикуспидального, аортального и клапана легочной артерии, при этом за основу брались три критерия: характер потока крови, скорость, наличие и выраженность регургитации.

\section{3. БИОХИМИЧЕСКИЙ АНАЛИЗ КРОВИ}

Как уже отмечалось ранее, показателями любой дисплазии соединительной ткани служит дефицит магния в организме женщины и показатель уровня оксипролина.

Рассмотрим, как происходит анализ оксипропина в периферической крови. Для этого в 3 цетрифужные пробирки выливают по 1 мл исследуемой сыворотки или плазмы крови, 0,05 мл хлорной кислоты и 0,5 мл трихлоруксусной кислоты. Содержимое смешивается, нагревается до 75-80 $\mathrm{C}$ на кипящей водяной бане, охлаждается до $18-22^{\circ} \mathrm{C}$ и помещается в центрифугу на 5-6 минут, при этом количество оборотов должно быть равно 3000 об./мин. 
Остаточные образцы сыворотки и плазмы крови в определенном количестве помещаются в мерные центрифужные пробирки, 1-ю пробирку с содержимым необходимо поставить в воду со льдом или нейтрализовать содержимое, а 2-ю и 3-ю пробирки закрывают ретинальными каплеуловителями (часовое стекло), ставят на кипящую водяную баню на 40 мин. и охлаждают до $18-22^{\circ} \mathrm{C}$.

Содержимое пробирок после добавления к ним по одной капле раствора фенолфталеина нейтрализовали 6 мл раствора едкого калия, необходимо добиться появления устойчивой слабо пурпурной окраски по всему объему жидкости. Если появляется интенсивная окраска, то в смесь добавляют каплю хлористой кислоты, и вновь происходит процесс нейтрализации щелочью. Объем жидкости во всех пробирках вырос до 3,8-4 мл.

К 3 пробам (первые две являются опытными пробирками, третья - контрольной, в ней отсутствует НДСТ) при смешении компонентов добавляют по 0,5 мл раствора хлорамина, затем через 45 мин. В опытные пробы добавляется 0,5 мл хлорной кислоты и 0,5 мл реактива №6, а в контрольную пробу добавляют 0,1 мл хлорной кислоты и 0,5 мл этанола. Все смеси смешивают, нагревают до $75-80^{\circ} \mathrm{C}$ на водяной бане, затем охлаждают до $18-22^{\circ} \mathrm{C}$ и добавляют по 4 мл реактива №8. После этого содержимое всех пробирок встряхивают, загружают в центрифугу на 10 минут, при этом необходимы следующие параметры: 3000 об/мин., супернатант необходимо фотометрировать при длине волны 560 нм, в кюветах с длиной оптического пути 2 см.

Содержимое первой пробирки фотометрируют против реактива №8, второй пробирки - против контроля, в них наблюдается отсутствие хромогена, который характерен для оксипролина. Содержимое свободного (пробирка 1) и суммарного (пробирка 2) оксипролина рассчитывают по калибровочной кривой и выражают в микромолях на 1 л сыворотки крови. В случае наличия дефицита сыворотки крови можно анализировать лишь один из данных показателей. Учитывая разность между суммарным и свободным оксипролином, рассчитывается количество связанного оксипролина.

При биохимическом анализе уровня магния в периферической крови используют компьютерные программы и реактивы. Примерами такой программы является «Коне Ультра». 
При проведении биохимического анализа крови беременных женщин исследуется сразу несколько показателей. Приведем сводную таблицу показателей, которые подвергаются исследованию. В ней приведены данные нормального количества всех веществ.

\section{Методы исследования плода}

На данный момент наиболее часто применяются методы, связанные с определением и контролем сывороточных белков.

Альфа-фетопротеин (АФП) - специфический фетальный альфаглобулин. Необходим для транспортировки гормонов, аминокислот, микроэлементов к различным клеткам и тканям организма. Его возможно уже определить на 11-14-й неделе беременности. Максимально в крови плода может присутствовать 10\% данного белка. Анализ АФП применяется для определения срока беременности и зрелости плода, а также для прогнозирования синдрома дыхательной недостаточности при рождении.

Хорионический гонадотропин человека (хориогонадотропин, ХГЧ) - гликопротеин с молекулярной массой около $46000 \mathrm{D}$. Он состоит из двух нековалентно связанных субъединиц - альфа и бета. Только бета-субъединица иммунологически специфична для ХГЧ, поэтому специфическая антисыворотка у подавляющего большинства диагностических тест-систем направлена именно против бета-цепи. Именно ХГЧ может помочь установить беременность на очень раннем сроке.

Ультразвуковая диагностика является основным методом исследования плода на всей протяженности беременности. Основным принципом при проведении ультразвукового исследования является «Столь мало, сколько достижимо в разумных пределах».

C 3-й недели в полости матки можно уже обнаружить начало визуализации плодного яйца в виде эхонегативного образования округлой или овоидной формы диаметром 5-6 мм. В 4-5 недель уже появляется эмбрион размером 6-7 мм. Головка эмбриона полностью визуализируется с 8-9-й недели и имеет вид отдельного анатомического образования округлой формы средним диаметром 10-11 мм. Оценка жизнедеятельности эмбриона в ранние сроки беременности основывается на регистрации его сердечной деятельности и двигательной активности. 
При УЗИ регистрировать сердечную деятельность эмбриона можно с 4-5-й недели. Двигательная активность эмбриона выявляется с 7-8-й недели. При изучении развития плода во II и III триместрах беременности измеряют следующие размеры: бипариетальный размер, окружность головки, средние диаметры грудной клетки и живота, длину бедренной кости. Ультразвуковое исследование позволяет проводить оценку деятельности различных органов и систем плода, а также диагностировать врожденные пороки его развития. Для их детальной оценки может использоваться трехмерная эхография, позволяющая получить объемное изображение. При трансвагинальном исследовании четкое изображение хориона можно получить с 5-6-й недели беременности. Одним из показателей состояния плаценты является ее толщина. К 36-37-й неделе рост плаценты прекращается. В дальнейшем при физиологическом течении беременности ее толщина уменьшается или остается на том же уровне, составляя 3,3-3,6 см.

Децелерации (урежения) - это кратковременные уменьшения ЧСС на 15 в 1 мин. Г.М. Савельева с соавт. (2000) приводят критерии, которые характерны для нормальной КТГ:

а) базальный ритм в диапазоне 120-160 уд/мин;

б) амплитуда осцилляций - 5-25 уд/мин;

в) децелерации отсутствуют;

г) акцелерации 2 и более за 10 мин.

С целью унификации оценки данных антенатальной КТГ предложена балльная система (Fischer W. et al., 1976; Г.М. Савельева и др., 1984) (таблица 3).

Оценка 8-10 баллов - удовлетворительное состояние плода, 57 баллов - начальные признаки нарушения жизнедеятельности плода, 4 балла и менее - серьезные изменения состояния плода.

Амниоскопия - эндоскопический метод, позволяющий на основании ряда визуальных признаков оценить состояние плода.

К инвазивным методам получения плодного материала относятся хорионбиопсия, плацентобиопсия и амниоцентез. В отдельных случаях исследуют непосредственно клетки плода, что достигается с помощью кордоцентеза. Данные методы используются для получения материала для цитогенетических, молекулярных, цитохимических, биохимических и других исследований. 
После детального применения определенной совокупности методов исследования протекания беременности и состояния плода можно приступить к прогнозированию течения родов. В ходе данного прогнозирования учитывается множество факторов, оно составляется при помощи компьютерных программ. Можно спрогнозировать возможные осложнения родов, оценку новорожденных по шкале Апгар, продолжительность родов, продолжительность безводного промежутка и т. д. 


\section{ГЛАВА З. МАТЕМАТИЧЕСКОЕ ПРОГНОЗИРОВАНИЕ ТЕЧЕНИЯ РОДОВ У ЖЕНЩИН С ДИСПЛАЗИЕЙ СОЕДИНИТЕЛЬНОЙ ТКАНИ}

В настоящее время прогнозирование протекания тех или иных процессов в организме человека активно применяется в современной медицине и здравоохранении. Оно необходимо для оптимизации мер в здравоохранении по предотвращению нежелательных последствий. В акушерстве прогнозирование широко применяется для определения слабости родов, необходимости и исхода кесарева сечения, определения протекания беременности при пиелонефрите и отрицательном резусе-факторе у беременных ${ }^{28}$. При наличии у беременной недифференцированной дисплазии соединительной ткани прогнозируются возможные осложнения протекания беременности и родов.

Любое прогнозирование течения и исхода родов проводится при анализе исследования женщин и плода методами, указанными в главе 2.

В работах Б. Лоуеса, У. Шварца, Т. Холма можно найти описания применения математического прогнозирования осложнений протекания беременности и родов у женщин с недифференцированной дисплазией соединительной ткани ${ }^{29}$.

Т.С. Лукина в своей статье «Оптимизация математического моделирования и прогнозирования анализа течения беременности и родов у женщин с недифференцированной дисплазией соединительной ткани» приводит разработанный ею пакет программного обеспечения, который позволяет провести математическое прогнозирование по наличию/отсутствию клинических симптомов и синдромов у беременных женщин ${ }^{30}$. При построении данного пакета программного обеспечения учитывались статистические методы исследования посредством использования конкретных программ.

\footnotetext{
${ }^{28}$ Елисеева И.В. Особенности течения беременности и родов у женщин с пролапсом митрального клапана: Автореф. дис. ... канд. мед. наук. - М., 2003. - 21 с.

${ }^{29}$ Loyes B.L., Schwarze U., Holm T., Callewaert B.L., Thomas G.H. Aneyrysm syndromes caused by mutation in the TGF-beta receptor // Med. - 2006. Vol. 355 (8). - P. 788-798.

30 Лукина Т.С. Оптимизация математического моделирования и прогнозирования анализа течения беременности и родов у женщин с недифференциальной дисплазией соединительной ткани. - Чебоксары: ЦНС «Интерактив плюс», 2009. - С. 78-79.
} 


\section{1. КОМПЬЮТЕРНАЯ ПРОГРАММА «ШАГ К DST»}

Данная программа позволяет провести расчет степени дифференциальной дисплазии соединительной ткани на основании определенных данных. Она осуществляет работу на операционной системе не ниже Windows 2000. Написана на языке Delphin 5.0 с использованием стандартных компонентов.

Данная программа содержит интуитивно-понятный интерфейс, который позволяет пользователю выбрать необходимые для заполнения поля. При выборе необходимых полей осуществляется переход по записям, все поля автоматически заносятся в базу данных и затем проводится расчет по заданным показателям. В программе используется база данных dBase, все файлы сохраняются в формате «.dbf».

Обязательными для заполнения являются поля «ФИО» и «Возраст». Затем при использовании кнопки перехода осуществляется заполнение остальных полей. Для визуального контроля оценки существует кнопка «Выбор формы». После заполнения всех данных и выбора необходимых параметров необходимо нажать кнопку «Рассчитать», после чего проводится расчет по уже разработанному алгоритму действий. По итогам работы программы на экран выводятся данные по наличию той или иной степени дифференциальной дисплазии соединительной ткани, а данные результаты заносятся в базу данных.

Все уже занесенные записи можно редактировать или удалять, распечатывать в выбранной пользователем форме.

\section{2. ПРОВЕРКА ПАКЕТА ПРОГРАММНОГО ОБЕСПЕЧЕНИЯ, РАЗРАБОТАННОГО Т.С. ФАДЕЕВОЙ}

Для проверки пакета программного обеспечения, разработанного Т.С. Фадеевой и приведенного в ее диссертации «Оптимизация математического моделирования и прогнозирование анализа течения беременности и родов у женщин с недифференцированной дисплазией соединительной ткани» ${ }^{31}$ было проведено исследова-

\footnotetext{
31 Лукина Т.С. Оптимизация математического моделирования и прогнозирования анализа течения беременности и родов у женщин с недифференциальной дисплазией соединительной ткани: Автореф. дис. ... канд. мед. наук. - М., 2003. -152 с.
} 
ние анамнеза, течения и исхода беременности и родов у 950 беременных с недифференцированной дисплазией соединительной ткани. Из них 230 принимали магний, а остальные его не получали. Для построения математической модели были использованы показатели выборки, включающей 420 беременных женщин с недифференцированной дисплазией соединительной ткани.

Для построения математической модели использовались статистические методы анализа при наличии висцерального и локомоторного проявления недифференцированной дисплазии соединительной ткани, которые оказывают наибольшее влияние на протекание и исход родов. Для этого все данные, необходимые для проведения статистического анализа, переносятся в таблицу исходных данных, представленную в электронной форме. В таблицу заносятся как текстовые, так и числовые данные. Для текстовых данных, которые тоже представляют определенные переменные при расчете прогноза течения и исхода беременности и родов, используется соглашение «двойной записи». Данное соглашение позволяет присвоить текстовым данным числовое значение, а коды (номера) присвоения фиксировались в соответствующей таблице. Примеры таблицы соответствий между текстовыми и числовыми данными приведены в таблице 2 .

Таблица 2

Соответствие между текстовыми и числовыми значениями дисплатикозависимых изменений

\begin{tabular}{|l|c|l|}
\hline \multicolumn{1}{|c|}{ Фактор } & Код & \multicolumn{1}{|c|}{ Значение } \\
\hline \multirow{3}{*}{$\begin{array}{l}\text { изменение грудной клетки } \\
\text { (GG) }\end{array}$} & 0 & нет \\
\cline { 2 - 3 } & 1 & воронкообразная \\
\cline { 2 - 3 } & 2 & килевидная деформация \\
\hline \multirow{4}{*}{ изменения позвоночника (PZ) } & 0 & нет \\
\cline { 2 - 3 } & 1 & сколиоз грудного отдела \\
\cline { 2 - 3 } & 2 & «прямая» спина \\
\cline { 2 - 3 } & 3 & сколиоз поясничного отдела \\
\cline { 2 - 3 } & 4 & кифоз \\
\cline { 2 - 3 } & 5 & лордоз \\
\hline
\end{tabular}




\begin{tabular}{|l|l|l|}
\hline \multirow{2}{*}{$\begin{array}{l}\text { изменение органов дыхания } \\
\text { (OD) }\end{array}$} & 0 & нет \\
\cline { 2 - 3 } & 1 & гипоплазия легкого \\
\cline { 2 - 3 } & 2 & бронхоэктазы \\
\cline { 2 - 3 } & 3 & поликистоз легких \\
\hline аномальное расположение & 0 & нет \\
\cline { 2 - 3 } $\begin{array}{l}\text { хорды (RH) } \\
\text { варикозное расширение вен } \\
\text { (VR) }\end{array}$ & 1 & есть \\
\cline { 2 - 3 } & 1 & нет \\
\hline
\end{tabular}

Каждая модель имеет свой отклик, то есть результат моделирования. Если есть возможность осложнения беременности, ставится 0, а если нет, то 1 . К числу возможных осложнений относят анемию, артериальную гипертензию, поздний гестоз, преждевременные роды, несвоевременное излитие околоплодных вод, первичную слабость схваток, внутриутробную гипоксию, ЗВУР, недоношенность.

Согласно пакету программного обеспечения, разработанного Т.С. Лукиной, для эффективного составления прогноза течения и исхода беременности и родов используется 350 показателей по каждому варианту недифференцированной дисплазии соединительной ткани ${ }^{32}$, а чтобы рассчитать зависимость данных показателей, необходимо рассчитать коэффициент корреляции.

Под коэффициентом корреляции двух случайных функций X, Y понимается величина, которая находится по формуле:

$$
R(x, y)=\frac{\operatorname{Cov}(x, y)}{\sqrt{D X * D Y}}
$$

Коэффициент корреляции является нормированной ковариацией, то есть величиной двух случайных функций X,Y, при расчете которой применяется показатель Е - математическое ожидание.

Любое значение коэффициента корреляции находится на отрезке от -1 до 1 .

При наличии зависимости между X и $\mathrm{Y}$, то:

$$
\mathrm{Y}=\mathrm{a} * \mathrm{X}+\mathrm{b}
$$

где: $\mathrm{a}, \mathrm{b}-$ некоторые константы, то $[\mathrm{R}(\mathrm{X}, \mathrm{Y})]=1$

32 Лукина Т.С. Оптимизация математического моделирования и прогнозирования анализа течения беременности и родов у женщин с недифференцированной дисплазией соединительной ткани: Автореф. дис. ... канд. мед. наук. - М., 2003. 79 c. 
Более точно:

$$
\mathrm{R}(\mathrm{X}, \mathrm{Y})=1 \text {, если a }>0, \mathrm{R}(\mathrm{X}, \mathrm{Y})=-1 \text {, если } \mathrm{a}<0 .
$$

Если зависимость отсутствует, то присутствует нулевая корреляция.

После проведения расчётов корреляции можно построить матрицу корреляции для всех диспластикозависимых изменений и осложнений беременности и родов. Она приведена в таблице 3.

Таблица 3

\begin{tabular}{|c|c|c|c|c|c|c|c|c|c|}
\hline & GG & PZ & OD & SS & RH & VR & KT & PH & COD \\
\hline GG & 1.000 & 0.042 & 0.010 & -0.547 & 0.492 & 0.281 & 0.010 & 0.010 & 0.629 \\
\hline PZ & 0.042 & 1.000 & 0.010 & 0.099 & -0.385 & 0.279 & 0.010 & 0.010 & -0.507 \\
\hline OD & 0.010 & 0.010 & 1.000 & 0.010 & 0.010 & 0.010 & 0.021 & 0.010 & 0.510 \\
\hline SS & -0.547 & 0.099 & 0.010 & 1.000 & -0.685 & -0.279 & 0.010 & 0.130 & 0.641 \\
\hline RH & 0.492 & -0.385 & 0.010 & -0.685 & 1.000 & -0.057 & 0.010 & 0.010 & -0.366 \\
\hline VR & 0.281 & 0.279 & 0.010 & -0.279 & -0.057 & 1.000 & 0.010 & 0.010 & -0.563 \\
\hline KT & 0.010 & 0.010 & 0.021 & 0.010 & 0.010 & 0.010 & 1.000 & 0.010 & 0.612 \\
\hline PH & 0.010 & 0.010 & 0.010 & 0.130 & 0.010 & 0.010 & 0.010 & 1.000 & 0.710 \\
\hline COD & 0.629 & -0.507 & 0.510 & 0.641 & -0.366 & -0.563 & 0.612 & 0.710 & 1.000 \\
\hline
\end{tabular}

Для проверки точности расчетов коэффициентов корреляции можно определить оценку значимости. A $\mathrm{R}$ должно равняться математическому ожиданию Е и дисперсии $\sigma^{2}$, которые можно найти по следующим формулам:

$$
\begin{gathered}
\mathrm{E}(\mathrm{R}) \approx \rho, \\
\sigma^{2}(\mathrm{R}) \approx \frac{(1-\rho 2) 2}{n},
\end{gathered}
$$

При этом под n обозначают число выборки.

Для построения критериев значимости для $\rho$ используются доверительные интервалы. Исходя из нашего объема выборки, следует 100(1- $\alpha) \%$ доверительный интервал, который зависит от значений $\mathrm{R}$ и $\mathrm{n}$. Для проверки гипотезы значимости используется следующая формула:

$$
\mathrm{H}_{0} / \rho=\rho_{0}
$$

А значение $\rho_{0}$ находится по матрице корреляции.

Гипотеза принимается лишь в том случае, если $\rho_{0}$ находится в доверительном интервале, иначе она отвергается. 
Однако данную гипотезу можно проверить и при помощи статистических показателей, в данном случае применяют аппроксимацию, которая была предложена Фишером:

$$
Z=1 / 2 \operatorname{Ln}\left(\frac{1+\mathrm{R}}{1-\mathrm{R}}\right)
$$

Данная формула верна по нормальному закону распределения с математическим ожиданием:

И дисперсией:

$$
\mathrm{E}(\mathrm{Z}) \approx 1 / 2 \operatorname{Ln}\left(\frac{1+\mathrm{R}}{1-\mathrm{R}}\right)
$$

$$
\sigma_{\mathrm{z}}^{2} \approx(\mathrm{n}-3)^{-1}
$$

Для проверки гипотезы необходимо из матрицы корреляции найти число R, которое применяется для оценки $\rho$, а затем вычислить число $Z$. Нормальное распределение, математическое ожидание, равное 0 , и дисперсию, равную 0 , можно обнаружить при $\rho=\rho_{0}$.

Чаще всего уровень значимости лежит на $\alpha=0,05$, а объем выборки для каждого типа НДСТ и возможных осложнений беременности и родов одинаков и равен n-350.

Были проведены расчеты исходных величин, коэффициенты корреляции которых имеют зависимую величину больше 0,3 и лежат в 95\% доверительных интервалах.

Таблица 3

Значимые клинические типы НДСТ для построения математической модели

\begin{tabular}{|c|c|c|c|c|c|c|c|}
\hline $\begin{array}{c}\text { Пози- } \\
\text { ция }\end{array}$ & $\mathrm{R}$ & $Z$ & $\sigma-Z$ & $\operatorname{Min}(\mathrm{E})$ & $\operatorname{Max}(\mathrm{E})$ & $\operatorname{Min}(\rho)$ & $\operatorname{Max}(\rho)$ \\
\hline GG & 0.629 & 0.310 & 0.030 & 0.369 & 0.250 & 0.353 & 0.245 \\
\hline PZ & -0.507 & -0.310 & -0.30 & -0.250 & -0.369 & -0.245 & -0.353 \\
\hline OD & 0.510 & 1.099 & 0.030 & 1.039 & 1.158 & 0.777 & 0.820 \\
\hline SS & 0.641 & 0.424 & 0.030 & 0.364 & 0.483 & 0.349 & 0.449 \\
\hline VR & -0.563 & -0.549 & 0.030 & -0.609 & -0.490 & -0.543 & -0.454 \\
\hline KT & 0.612 & 0.549 & 0.030 & 0.609 & 0.490 & 0.543 & 0.454 \\
\hline RH & 0.710 & 0.549 & 0.030 & 0.609 & 0.490 & 0.543 & 0.454 \\
\hline
\end{tabular}


Таким образом, в таблице представлены все типы НДСТ, которые в большей степени оказывают влияние на течение беременности и исход родов для матери и ребенка. Порядок расположения данных типов НДСТ зависит от убывания величин коэффициента корреляции. Затем необходимо провести ранжирование данного списка по влиянию, которые они оказывают на течение беременности и исход родов. Это позволит отобрать независимые величины, которые в дальнейшем входят в математическую модель прогнозирования.

Еще одним важным фактором при построении математической модели прогнозирования является учет уровня FLT и PIGF в сыворотке крови матери. Согласно работам таких авторов, как Rayburn, W.F. и M.E. Fontana, уровень FLT и PIGF в сыворотке крови будет различаться у пациенток с преэклампсией и ЗРП ${ }^{33}$.

Все обследованные нами женщины с НДСТ были разделены на три группы в зависимости от возникновения акушерской патологии. Количество женщин, у которых диагностирован синдром задержки развития плода, составило 70. Беременные с преэклампсией составили 41. Для сравнения было решено сформировать группу беременных из 300 человек методом случайного подбора без преэклампсии и признаков ЗРП.

Отметим, что медиана балльной оценки выраженности НДСТ у женщин с преэклампсией составила 9 баллов, у беременных с ЗРП - 7 баллов, а у условно здоровых данный показатель равен 5.

У всех обследованных женщин проводился забор венозной крови до родоразрешения с целью определения содержания FLT и PIGF в сыворотке крови.

Для сравнения непрерывных величин был использован тест Манна - Уитни. При анализе результатов было выявлено, что среднее значение показателей FLT и PIGF в группе с преэклампсией достоверно отличалось от группы контроля. В то время как в группе с ЗРП достоверно отличался лишь уровень FLT.

При помощи метода бинарной логистической регрессии были определены истинно положительные, ложноположительные, ис-

\footnotetext{
${ }^{33}$ Rayburn, W.F. and M.E. Fontana, Mitral valve prolapse and pregnancy. Am J Obstet Gynecol, 1981. 141 (1): 9-11.
} 
тинно отрицательные и ложноотрицательные признаки. Точка отсечки для FLT - 5700 (чувствительность и специфичность составили $73,4 \%$ и 93,2\% соответственно), а для PIGF - 350 (чувствительность и специфичность составили 91,8\% и 83,0\% соответственно). Также нами произведен ROC-анализ для каждого признака.

Таким образом, уровень содержания FLT и PIGF можно использовать как диагностические критерии развития ЗРП или ПЭ. В случае, если уровень FLT выше 5700, а содержание PIGF ниже 350, то, скорее всего, у женщины имеется такое осложнение беременности, как преэклампсия. Если PIGF ниже 350, а FLT при этом не превышает 5700, то речь может идти о задержке развития плода.

Для обнаружения дополнительных факторов риска развития данных патологий было решено произвести анализ результатов молекулярно-генетического исследования. По полученным данным определено, что у пациенток с преэклампсией IL6: -174 C > G частота редкого генотипа $\mathrm{C} / \mathrm{C}$ составляет 50\%, у пациенток с СЗРП и без этих признаков частота редкого генотипа составила $25,0 \%$ и $20,8 \%$ соответственно. Встречаемость аллеля С больше, чем у половины, и составляет $67,9 \%$.

Применив метод бинарной логистической регрессии, на основании клинико-анамнестических и молекулярно-генетических данных определена вероятность развития рождения маловесного ребенка по формуле:

$$
\mathrm{P}=1 /(1+\mathrm{e}-\mathrm{z})
$$

где е - основание натурального логарифма и имеет значение 2,71828182845904;

$$
\begin{gathered}
\mathrm{z}=0,93+0,314 * \mathrm{X} 1+0,205 * \mathrm{X} 2+2,15 * \mathrm{X} 3+0,876 * \mathrm{X} 4+3,41 * \\
\mathrm{X} 5+0,63 * \mathrm{X} 6+0,59 * \mathrm{X} 7
\end{gathered}
$$

где X1 угроза прерывания в первом триместре, X2 - угроза прерывания во втором триместре, X3 - обострение хронических заболеваний МВС, Х4 угроза преждевременных родов, X5 - ЗРП, Х6 VEGFA: -634 G-C 3 (G/G кодируется как 1, G/C как 2, C/C как 3), X7 - VEGFA: 936 C-T (C/C кодируется как 1, С/Т как 2, Т/Т как 3)

Используя 90 и 10\% перцентили, определены границы степеней вероятности развития рождения маловесного плода.

Так, нами были сформированы 3 группы пациенток:

- с низкой вероятностью $(\mathrm{p}<=10 \%) \mathrm{z}=0-0,39$; 
- с умеренной вероятностью (р от 10 до 90\%) z =0,4-0,79;

- с высокой вероятностью - $\mathrm{p}=0,8-1,0$.

На основе программы Excel была создана программа прогнозирования рождения маловесных детей. Факторы риска вводятся в соответствии с его наличием (0 - отсутствует фактор, 1 - фактор присутствует). Данная модель имеет чувствительность $72 \%$ и специфичность 78\%. Образец модели представлен на рис. 5.2.6.

По результатам анализа угроза преждевременных родов имела корреляционную зависимость со множественными факторами: прямая слабая зависимость с выраженностью балльной оценки НДСТ по степеням $(\mathrm{R}=0,192 \mathrm{p}<0,05)$; прямая слабая зависимость с угрозой прерывания беременности в первом триместре беременности $(\mathrm{R}=0,251 \mathrm{p}<0,05)$; прямая умеренная зависимость с угрозой прерывания во втором триместре беременности $(\mathrm{R}=0,293 \mathrm{p}<0,05)$; прямая слабая зависимость с бесплодием I $(\mathrm{R}=0,217 \mathrm{p}<0,05)$; прямая слабая зависимость с варикозной болезнью $(\mathrm{R}=0,198 \mathrm{p}<0,05)$; прямая слабая зависимость с ММР9: $855 \mathrm{~A}>\mathrm{G}(\mathrm{R}=0,243 \mathrm{p}<0,05)$. Точно так же, как и в первой модели, методом бинарной логистической регрессии определена вероятность развития угрозы преждевременных родов.

$$
\begin{gathered}
\mathrm{z}=4,53-0,704 * \mathrm{X} 1-0,582 * \mathrm{X} 2-1,05 * \mathrm{X} 3-1,0 * \\
\mathrm{X} 4+3,41 * \mathrm{X} 5+0,63 * \mathrm{X} 6
\end{gathered}
$$

где X1 - выраженность бальной оценки НДСТ по степеням (слабой степени - 1 балл, умеренной - 2 балла, высокой - 3 балла); X2 угроза прерывания в первом триместре, X3 - угроза прерывания во втором триместре, X4 - первичное бесплодие, X5 - варикозная болезнь, X6 - VEGFA: -634 G-C 3(G/G кодируется как 1, G/C как 2, $\mathrm{C} / \mathrm{C}$ как 3). Данная модель имеет чувствительность 58\% и специфичность $89 \%$.

Однако построение математической модели прогнозирования лишь на основании показателей уровня FLT и PIGF в сыворотке крови матери будет не столь состоятельно, как если строить модель на основе как коэффициентов корреляции, так и на анализе сыворотки крови матери в совокупности. Это позволяет построить математическую модель прогнозирования, которая может применяться для верификации риска развития преждевременных родов у женщин с НДСТ. 
При дальнейшем построении математической модели прогнозирования применяется регрессионный анализ, что основывается на существовании математического соотношения между показателями обследуемого субъекта у и детерминируемыми его величинами $\mathrm{x}, \mathrm{X}_{1} \ldots . \mathrm{x}_{\mathrm{n}}$.

В связи с тем, что в данной работе был проведен эксперимент, большее значение имеет следующее представление влияния переменных $\mathrm{x}, \mathrm{x}_{1} \ldots \mathrm{x}_{\mathrm{n}}$ на $\mathrm{y}$ :

$$
\mathrm{Y}=\mathrm{f}\left(\mathrm{x}, \mathrm{x}_{1} \ldots . \mathrm{x}_{\mathrm{n}}\right)+\xi
$$

При этом под $\xi$ понимается случайная величина, которой присуще нормальное распределение с нулевым математическим ожиданием. A $\mathrm{f}\left(\mathrm{x}, \mathrm{x}_{1} \ldots \mathrm{x}_{\mathrm{n}}\right)$ представляет собой условное математическое ожидание значения у при следующих значениях факторов $\mathrm{x}, \mathrm{x}_{1} \ldots \mathrm{x}_{\mathrm{n}}$ :

$$
\mathrm{f}\left(\mathrm{x}, \mathrm{x}_{1} \ldots . \mathrm{x}\right)=\mathrm{M}\left(\frac{y}{\mathrm{x}, \mathrm{x} 1 \ldots \mathrm{xn}}\right)=\bar{y}(\mathrm{x}, \mathrm{x} 1 \ldots \mathrm{xn})=\bar{y}(\mathrm{x})
$$

Равенство $\left(\mathrm{x}, \mathrm{x}_{1} \ldots \mathrm{x}_{\mathrm{n}}\right)=\mathrm{X}$ является вектором значений входных переменных. Оно может служить в качестве точки к-мерного фактора пространства переменных х, $\mathrm{x}_{1} \ldots . \mathrm{x}_{\mathrm{n}}$.

Однако проведение данных расчетов нацелено на вычисление зависимости по данным проведенного исследования, которая находится по уравнению регрессии:

$$
\bar{y}(\mathrm{x})=\beta_{0} x_{0}+\beta_{1} x_{1}+\ldots+\beta_{i} x_{i}+\beta_{|+|} x_{|+|}+\ldots+\beta_{k} x_{k}=\sum_{i=0}^{k} \beta_{i} x_{i}
$$

При реализации регрессивного анализа необходимо найти экспериментальное определение коэффициентов регрессии $\beta_{i}$ по наличию входных переменных $\mathrm{x}, \mathrm{x}_{1} \ldots \mathrm{x}_{\mathrm{n}}$ выходной переменной $\mathrm{y}$.

Точное определение коэффициента регрессии $\beta_{i}$ при сравнительно небольшом числе обследуемых невозможно, поэтому необходимо ввести ограничение нахождения оценок $\hat{\beta}_{i}=b_{i}$ для данных коэффициентов. Следовательно, уравнение регрессии будет уже следующим:

$$
\hat{y}=\sum_{i=0}^{m} b_{i} x_{i}
$$

По данной формуле уже вычисляется не математическое ожидание $\bar{y}(\mathrm{x})$, а оценка математического ожидания $\hat{y}(\mathrm{x})$. 
Для любого уравнения регрессии характерно наличие $\mathrm{k}+1$ неизвестных коэффициентов регрессии, а чтобы их правильно определить, необходимо провести ряд экспериментов, в которых последовательно изменяются значения всех вводных и выводных данных. При проведении экспериментов следует обратить внимание на то, что общее число обследованных n не должно быть меньше, чем неизвестных коэффициентов регрессии.

Степенью свободы называется разность между числом наблюдений и числом неизвестных параметров, которая оценивается посредством проведенных наблюдений. При регрессивном анализе степень свободы вычисляется следующим образом:

$$
\mathrm{N}=\mathrm{n}-(\mathrm{k}+1)
$$

Выбор регрессионной модели зависит от выбора вида функций, которыми оперируют в ходе проведения эксперимента. Чаще всего полученные данные могут быть аппроксимированы с необходимой точностью функциями разного вида, следовательно, выбор функций не должен быть только автоматическим посредством математических алгоритмов и механизмов формализации. Основной моделью все же является степень полиномного вида:

$$
\mathrm{y}=b_{1}+b_{2} x+b_{3} x^{3}+\ldots+b_{m} x^{m-1}
$$

При этом параметрами модели являются $b_{1}, b_{2} \ldots b_{m}$.

Однако данная формула требует более подробного разложения, которое основывается на том, что откликами являются непрерывные функции, которые неразрывны от факторов, следовательно, при разложении можно использовать ряд Тейлора. Модель, основанная на данном разложении, позволяет получить более точную аппроксимацию истиной зависимости. Еще одним достоинством модели, построенной на разложенной функции, является то, что функция будет линейной относительно неизвестных коэффициентов $b_{1}, b_{2} \ldots b_{m}$, что делает заметно проще процедуру наблюдения. Теперь уже выбор модели зависит не от функций, а от выбора порядка m-1 полинома.

Затем, когда выбор модели состоялся, производится вычисление ее параметров. Для модели оценки коэффициентов $b_{1}, b_{2} \ldots b_{m}$ определяются методом наименьших квадратов ${ }^{34}$.

\footnotetext{
${ }^{34}$ Chen C, Hill L.D., Wan L., Chung Y.W., Chen W.C., Tsay F.J., Tsay C.H. Estrogen receptor beta gene haplotype is associated with pelvic organ prolapse // Eur J Obstet Gynecol Reprod Biol. - 2008. - Vol. 138. - №1. - P. 105-109.
} 
Для проверки правильности выбора степени полинома необходимо провести анализ F-критерия, который определяется через сумму $S_{R}^{2}$ квадратов отклонений экспериментальных значений у ${ }^{1}$ от значений $\mathrm{y}^{2}$, которое рассчитывается по уравнению регрессии:

$$
S_{R}^{2}=\sum^{n}\left(\hat{y}_{i}-y_{i}\right)^{2}
$$

Остаточную дисперсию можно найти путем деления данной суммы на степени свободы: $\mathrm{N}=\mathrm{n}-(\mathrm{k}+1)$, что характеризует рассеяние экспериментальных точек относительно найденного уравнения регрессии:

$$
S_{R}^{2}=\frac{S_{R}^{2}}{\mathrm{~N}=\mathrm{n}-(\mathrm{k}+1)}
$$

Однако для построения релевантной модели необходимо вычислить дисперсию $S_{\mathrm{y}}^{2}$, что необходимо для характеристики погрешности эксперимента:

$$
S_{\mathrm{y}}^{2}=\frac{1}{n-1} \sum_{i=1}^{n}\left(\hat{y}_{i}-y_{i}\right)^{2}
$$

где:

$\mathrm{n}-1$ - число степеней свободы при определении дисперсии $S_{\mathrm{y}}^{2}$;

$\hat{y}_{i}$ - выборочное среднее значение по всем результатам эксперимента.

Таким образом, F-критерий можно найти по формуле:

$$
\mathrm{F}=S_{R}^{2} / S_{\mathrm{y}}^{2}
$$

Затем необходимо снова проверить гипотезу об адекватности представления результатов полиномом заданной степени $\mathrm{d}$ путем сопоставления вычисленного значения $\mathrm{F}$ со значением $\mathrm{F}_{\mathrm{q}}$, найденным из таблиц F-распределения при заданных степенях свободы N и $\mathrm{n}-1^{35}$.

Расчет степени полинома в ходе проведенного исследования проводился по шагам, первый из которых состоял из оценки коэффициентов самой простой, линейной, относительно факторов модели. После чего необходимо проверить, насколько хорошо согласуются в модели значения отклика и с результатами наблюдений. В том случае, если модель окажется неадекватной, то есть будет

\footnotetext{
${ }^{35}$ Клеменов А.В. Течение и исход беременности у женщин с недифференциальной дисплазией соединительной ткани / А.В. Клеменов, О.П. Алексеева, А.А. Востокова и соавт. // Тер. архив. - 2003. - №4. - С. 44-46.
} 
наблюдаться несоответствие отклика с результатами наблюдений, то модель необходимо изменить, данные снова подвергнуть тщательному отбору, что приведет к возникновению новых оценок регрессии. Процесс проверки модели на адекватность и ее последующую модернизацию длится до того момента, когда в ходе расчетов получаем удовлетворяющее согласование данных наблюдения и значения.

По результатам проведенного исследования было выявлено, что в большей степени на течение беременности и исход родов влияют такие факторы, как:

1. Деформация грудной клетки.

2. Изменения позвоночника (сколиоз, кифоз, лордоз, «прямая» спина).

3. Изменения сердечно-сосудистой системы (торакодиафрагмальное сердце, пролапсы сердечных клапанов, варикозное расширение вен, аневризма сосудов сердца).

4. Изменения желудочно-кишечного тракта.

5. Изменения почек (удвоение почек, нефроптоз).

Процедура построения линейного регрессионного уравнения для отклика СОД была начата с отбора основных независимых переменных из общего списка переменных. Данный отбор проводился на основе статистических методов, учитывался и шаговый регрессионный метод ${ }^{36}$. Все это позволило более рационально рассчитать время проведения эксперимента, все данные подвергались обработке на ЭВМ, осуществлялось ранжирование результатов в зависимости от их влияния на течение беременности и родов у женщин с недифференцированной дисплазией соединительной ткани, все это заметно упростило работу с большим количеством числовых данных.

Вся процедура отбора коэффициента корреляции подвергалась жесткому отбору, регламентируемому определенным алгоритмом действий:

1. Выбирается величина $\mathrm{X}$, которая находится в коррелятивных отношениях с У.

\footnotetext{
${ }^{36}$ Небиеридзе Д.В. Метаболические и сосудистые эффекты антигипертензивной терапии / Д.В. Небиеридзе, Р.Т. Оганов. - М.: Универсум Паблишинг, 2005. $104 \mathrm{c}$.
} 
2. Определяется линейное первого порядка регрессивного уравнения, или, если данная величина отсутствует, то построение модели основывается на уравнении: $\mathrm{y}=\mathrm{k} * \mathrm{x}$. Все переменные фиксируются в модели.

3. Находятся частные коэффициенты корреляции для всех переменных $\left(\mathrm{X}_{\mathrm{j}}\right.$, при $\mathrm{j}$, не равном 1), данные коэффициенты не были учтены на предыдущих шагах.

4. Находится величина $\mathrm{X}_{\mathrm{j}}$, в которой находится апогей значения коэффициента корреляции с У, благодаря чему находится второе регрессионное уравнение: $\mathrm{y}=\mathrm{f}\left(\mathrm{x}_{1}, \mathrm{X}_{\mathrm{j}}\right)$.

5. Затем необходимо провести проверку уравнения на значимость.

6. После чего необходимо тщательное исследование F-критериев для обеих переменных, входящих в состав уравнения.

7. Наименьшая величина из данных двух частных F-критериев необходимо сравнить с подходящей процентной точкой F-распределения.

8. Проводится проверка всех переменных на значимость, в ряде случаев могут встречаться переменные, которые в зависимости от шага исследования утрачивают свою значимость и становятся непригодными для дальнейшего исследования.

9. Все незначимые переменные для исследования исключаются из него.

10. Затем необходимо провести перерасчет регрессионного уравнения, учитывая уже отсутствие ряда переменных в его составе.

11. Затем снова осуществляется проверка F-критерия на значимость. Если проверка проходит успешно, то ни одна переменная не будет признана незначимой, в противном случае необходимо повторить шаг 10 и 11 снова, пока результаты проверки не будут удовлетворяющими всем требованиям.

Для произведения всех расчетов в автоматическом режиме наиболее полезной является программа комплексного статистического анализа и обработки данных STATISTICA.

В ходе исследования был произведен анализ модели по всем описанным выше шагам. Была выявлена следующая модель:

$$
\begin{gathered}
\mathrm{COD}=10971.82+7457.73 * \mathrm{GG}-3991.13 * \mathrm{PZ}+4853.67 * \\
\mathrm{OD}-5207.67 * \mathrm{SS}+654.09 * \mathrm{VR}-18085.45 * \mathrm{KT}-671.27 * \mathrm{PH}
\end{gathered}
$$


Релевантность подобной модели оценивается посредством численных характеристик: $R^{2}=0,8661, \mathrm{~F}=1.506, \mathrm{P}<0,24534$. А коэффициент детерминации $R^{2}$ указывает, что построенная регрессия является высоко значимой и объясняет более $86 \%$ разброса возможных осложнений беременности и родов, которые могут остаться только угрозой, но и быть при этом реально опасными, так как могут наступить в любой момент, независимо от триместра.

Для правильной разработки программы математического прогнозирования возможных акушерских осложнений для беременных и плода была использована объектно-ориентированная среда Visual Basic, которая позволяла создать программу прогнозирования по отобранной нами модели, упростить алгоритм проверки, разработать интерфейс пользователя, кроме того, она позволяет вывести на экран результаты прогноза, которые формируются в качестве отчета по проделанной работе.

Проанализируем работу в объектно-ориентированной среде Visual Basic, которая осуществляется в программе «Step DST», которая широко описана Т.С. Лукиной, представленной в ее диссертационной работе ${ }^{37}$. По ее мнению, использование данной программы в акушерско-гинекологических отделениях поликлиник и женских консультациях способствует повышению эффективности прогнозирования недифференцированной дисплазии соединительной ткани и, как следствие, снизит риск возникновения возможных акушерских осложнений во время беременности и родов (угроза выкидыша, гестоз, гипоксия плода, анемия, обильное кровотечение при родах).

Кроме того, она позволяет своевременно выявить необходимость проведения той или иной медикаментозной терапии, например, необходимость проведения магниевой терапии, что также поможет свести к минимуму возникновение возможных осложнений при беременности и родах.

В основе данной программы - методы математического прогнозирования, которые были описаны выше. Интерфейс пользователя

\footnotetext{
37 Лукина Т.С. Оптимизация математического моделирования и прогнозирования анализа течения беременности и родов у женщин с недифференциальной дисплазией соединительной ткани: Автореф. дис. ... канд. мед. наук. - М., 2003. - 91 с.
} 
основывается на разработанной системе «Меню». Самое простое меню включает в себя следующие разделы:

1. Ввод данных.

2. Прогнозирование.

3. Формирование отчета.

4. Конец работы.

5. Просмотр и корректировка.

Однако при незначительной модернизации меню программы может претерпевать изменения.

На этапе прогнозирования осуществляется диалог врача и компьютера, который отображается на экране дисплея монитора, и по результатам данного диалога выводятся на дисплей монитора те диспластикозависимые изменения, прогностическое значение которых является наиболее значимым для составления адекватного ситуации прогноза.

В описанной выше программе можно редактировать записи, удалять какие-либо данные. Когда процесс заполнения определенной формы в математической программе подходит к концу, необходимо нажать кнопку «Рассчитать», только после этого программа осуществляет расчет степени дисплазии соединительной ткани по выбранному заранее алгоритму.

После разработанной модели и программы на ее основе проводился анализ релевантности работы программы, который заключался в прогнозировании течения беременности и родов у женщин с недифференцированной дисплазией соединительной ткани на основе анализа карт, однако у данных женщин уже был известен исход беременности и родов. Число карт для проведения диагностики было равно 260.

Все данные из карт вводились в ПЭВМ, затем осуществлялся автоматический прогноз по выбранной модели. Результаты прогноза сравнивались с действительными исходами беременности и родов. Результаты прогнозирования программы, которые совпали с ситуацией из карт, позволяют судить об адекватности и применимости на практике данной программы.

Всего выборка состояла из 800 записей, например:

1. Гипермобильность суставов.

2. Вегетососудистая дистония.

3. Индекс массы тела. 
4. Возраст.

5. Числовой параметр наследственности с НДСТ и т. д.

Необходимо отметить, что большинство переменных можно было рассчитать самостоятельно в программе, не имея точного диагноза.

Так, например, можно рассчитать чувствительность, которая определяется по следующей формуле:

$$
\text { Чувствительность }=\frac{R N}{R P+W N}
$$

Таким образом, в ходе проведенного исследования было установлено, что результаты прогноза вероятности возникновения осложнений беременности и родов у женщин с недифференцированной дисплазией соединительной ткани совпадали с их действительными исходами родов. У 150 пациенток число прогнозируемых осложнений превышало число действительных, а у 100 - течение беременности отмечалось с большим процентом осложнений, чем было отмечено в составленном прогнозе. Все это указывает на значимость разработанной модели и возможность ее дальнейшего использования в сфере прогнозирования. 


\section{ГЛАВА 4. ОПТИМИЗАЦИЯ МЕР ВЕДЕНИЯ БЕРЕМЕННОСТИ И РОДОВ У ЖЕНЩИН С ДИСПЛАЗИЕЙ СОЕДИНИТЕЛЬНОЙ ТКАНИ}

По данным Всемирной организации здравоохранения, не менее $20 \%$ случаев заболеваний среди всех женщин связаны с нарушениями репродуктивной функции. Следовательно, укрепление репродуктивного здоровья и охрана здоровья беременных женщин в настоящее время являются приоритетными и первоочередными для деятельности органов и учреждений здравоохранения ${ }^{38}$.

На данный момент разрабатываются и реализуются Федеральные программы и Государственные концепции по охране репродуктивного здоровья молодежи и беременных женщин ${ }^{39}$.

Согласно Государственной концепции по охране репродуктивного здоровья молодежи и беременных женщин на данный момент присутствуют негативные тенденции в показателях, характеризующих репродуктивное здоровье. Низкий уровень рождаемости и высокий показатель общей смертности населения способствуют снижению уровня воспроизводства населения, ухудшению качества здоровья детей. Все это связывается с ухудшениями условий проживания, социально-экономическими трудностями. Однако также подчеркивается наличие острых медико-социальных проблем в стране, что, в свою очередь, является фактором национальной безопасности ${ }^{40}$.

Основными задачами, которые преследовались во время создания и принятия данной концепции, являются:

- обеспечение государственной политики в области охраны репродуктивного здоровья населения России;

\footnotetext{
${ }^{38}$ Васильев В.Е. Пути совершенствования медико-социальной помощи женщинам и детям при угрозе невынашивания: Автореф. дис. ... канд. мед. наук. - СПб., 1994. - 17 c.

39 Фадеева Т.С. Беременность у женщин с дисплазией соединительной ткани // Вестник Российского Государственного медицинского университета. - 2007. №7. - C. 171-172.

40 Концепция охраны репродуктивного здоровья населения России на 20002004 годы // АВ. Охрана репродуктивного здоровья населения на 2000-2004 гг. 2001. - Вып. 8 [Электронный ресурс]. - Режим доступа: http://iam.duma.gov.ru/ node $/ 8 / 4534 / 15428$
} 
- увеличение объема мероприятий по профилактике нарушений репродуктивного здоровья населения;

- сокращение сроков восстановления утраченного здоровья путем внедрения в медицинскую практику современных технологий, профилактики, диагностики и лечения;

- реализация специальной научной программы;

- повышение квалификации специалистов, работающих в области охраны репродуктивного здравоохранения;

- активное участие общественности самого населения в охране репродуктивного здоровья.

Кроме того, ст. 38 Конституции РФ закреплено то, что материнство и детство и институт семьи находятся всецело под защитой государства. Ст. 41 Конституции РФ предусматривает финансирование федеральных программ охраны и укрепления здоровья населения, принимаются меры по развитию государственной, муниципальной, частной систем здравоохранения, поощряется деятельность, способствующая укреплению здоровья человека, развитию физической культуры и спорта, экологическому и санитарно-эпидемиологическому благополучию ${ }^{41}$.

Важнейшими национальными документами, направленными на реализацию государственной политики по охране материнства и детства, в настоящее время являются Основы государственной социальной политики по защите, развитию и выживанию детей, национальный план действий по улучшению положения женщин и повышению их роли в обществе до 2000 г., Концепции улучшения положения женщин и развития здравоохранения и медицинской науки в Российской Федерации, президентская программа «Дети России», включающая 11 целевых программ, направленных на решение самых острых проблем материнства и детства.

Основополагающие мероприятия по охране репродуктивного здоровья населения реализуются в рамках специальных федеральных целевых программ «Планирование семьи» и «Безопасное материнство», а также и других законодательных документов и федеральных целевых программ: федеральные законы «О предупрежде-

\footnotetext{
${ }^{41}$ Конституция Российской Федерации 2015 года [Электронный ресурс]. - Режим доступа: http://base.garant.ru/10103000/2/\#block_2000
} 
нии распространения в Российской Федерации заболевания, вызываемого вирусом иммунодефицита человека (ВИЧ-инфекции)», «О лекарственных средствах», «О наркотических средствах и психотропных веществах» и др.; федеральные целевые программы: «АнтиСПИД», «Неотложные меры борьбы с туберкулезом в России» и др.

В развитие федеральных законодательных актов и программ приняты и реализуются соответствующие документы в субъектах Российской Федерации.

Обеспечение конституционных прав граждан Российской Федерации на получение гарантированной бесплатной медицинской помощи осуществляется в рамках принятой Правительством Российской Федерации Программы государственных гарантий обеспечения граждан Российской Федерации бесплатной медицинской помощью.

Аборты по желанию (статья 36 Основ Законодательства об охране здоровья граждан Российской Федерации) производятся за счет средств обязательного медицинского страхования (ОМС).

В целях реализации настоящей Концепции необходимо обеспечение приоритетного гарантированного финансирования мероприятий по охране репродуктивного здоровья населения за счет бюджетов и источников всех уровней.

Для выполнения Концепции следует продолжить разработку и утверждение соответствующих нормативно-правовых актов и федеральных целевых программ.

Изучение влияния экстрагенитальной патологии женщины на течение беременности и родов является одним из самых важных направлений современного акушерства. Соматические заболевания во многих случаях не только предопределяют состояние женщины в гестационном периоде, но и, по данным ряда авторов, с ними связано 12-20\% материнской смертности и до $40 \%$ перинатальной заболеваемости. Причем в последние годы большое внимание уделяется экстрагенитальной патологии, обусловленной недифференцированной дисплазией соединительной ткани.

Частота недифференцированной дисплазии соединительной ткани (НДСТ) составляет от 20 до 30\% рожающего контингента 
женщин ${ }^{42}$. Генерализованный характер поражения соединительной ткани с вовлечением в патологический процесс репродуктивной системы не может не отразиться на течении беременности и исходе родов.

Проблема сочетания НДСТ и беременности содержит еще множество несогласованных вопросов: остается открытым вопрос о необходимости разработки организационно-методологической базы по дообследованию и лечению беременных с НДСТ и перинатальной профилактике патологии. Вопросы оказания медико-профилактической помощи и прогнозирования репродуктивных осложнений при наличии НДСТ также нуждаются в изучении, особенно с позиций математического моделирования заболевания. Фактически отсутствуют системные медико-организационные мероприятия по осуществлению дородовой подготовки женщин с НДСТ в учреждениях родовспоможения.

Необходимо отметить, что в настоящее время остро стоит вопрос о принятии Закона «О репродуктивных правах граждан и гарантиях их осуществления», а также внесении дополнений и поправок в Кодекс законов о труде Российской Федерации, Основ законодательства по охране труда в части, касающейся охраны труда и здоровья работающих.

\section{1. СИСТЕМА ПРОФИЛАКТИЧЕСКИХ МЕР ПО ОХРАНЕ РЕПРОДУКТИВНОГО ЗДОРОВЬЯ}

Концептуальной основой развития профилактических мероприятий должна стать ответственность за создание условий, вызывающих нарушения репродуктивного здоровья; профилактика и раннее выявление различных нарушений состояния здоровья населения, возникающие при воздействии производственных и факторов окружающей среды на репродуктивную функцию.

Необходимо разработать научно обоснованный перечень тяжелых работ и работ с вредными условиями труда, на которых не до-

\footnotetext{
42 Шибельгут Н.М. Течение беременности и исходы родов у женщин с недифференцированными формами дисплазии соединительной ткани / Н.М. Шибельгут, В.Г. Мозес, И.С. Захаров, Н.Б. Колесникова // Научно медицинский журнал. 2009. - №4. - С. 27-29.
} 
пускается (или регламентирован) труд женщин детородного возраста, в т. ч. беременных, подростков и инвалидов, предусмотрев сокращение рабочего времени их занятости с сохранением среднего заработка, а также осуществлять аттестацию рабочих мест для предотвращения риска нарушения репродуктивного здоровья работающих.

Обеспечить проведение сертификации постоянных рабочих мест, средств производства и оборудования с учетом факторов риска нарушений репродуктивного здоровья.

Целесообразно восстановить систему профилактических медицинских осмотров при приеме на работу и контактирующих в процессе работы с вредными и тяжелыми условиями труда.

Разработать механизмы квотирования, налоговых и иных льгот и т. п. для работодателей, использующих труд женщин, особенно беременных и кормящих матерей.

Предусмотреть ответственность работодателей и других официальных лиц за сокрытие информации о риске для репродуктивного здоровья работающих, рассматривая это как нарушение прав человека. Своевременно информировать работающих о риске нарушения репродуктивного здоровья и возможной патологии у детей при работе во вредных и тяжелых условиях. Предоставить женщине право выбора условий работы с подписанием контракта, в котором предусмотрена двусторонняя ответственность за возможные последствия нарушения здоровья.

Целесообразно решить вопрос о разработке системы социального страхования (в том числе обязательного медицинского страхования) дифференцированно по степеням профессионального риска и экологического неблагополучия территории в современных условиях.

Особое внимание должно быть обращено на охрану репродуктивного здоровья подростков:

- создание новых подходов к гигиеническому и половому воспитанию и просвещению детей и подростков, формированию здорового образа жизни и подготовке к семейной жизни, материнству и отцовству;

- использование образовательных учреждений для массового оздоровления и укрепления здоровья подростков. Создание и внед- 
рение в образовательный процесс эффективной системы физического воспитания, ориентированной на особенности развития детей и подростков;

- улучшение материально-технической базы образовательных, медицинских и оздоровительных учреждений. Создание оптимальных условий, соответствующих гигиеническим стандартам, на всех этапах образовательного процесса.

Совершенствование системы профилактических медицинских осмотров с целью активного выявления нарушений состояния здоровья, в т. ч. репродуктивного - у детей и подростков.

В охране репродуктивного здоровья особое место должно быть отведено профилактике абортов. В связи с этим необходимо:

- предупреждение нежелательных беременностей, снижение числа абортов, а также заболеваемости и смертности по причине аборта;

- обеспечение высококачественных услуг в области планирования семьи для всех, кто нуждается в них, с соблюдением конфиденциальности;

- повышение качества рекомендаций, информации, образования, просвещения, консультаций и услуг в области планирования семьи;

- вовлечение мужчин в решение проблем планирования семьи, повышение их ответственности и роли в семье.

Для снижения уровня патологии беременности и родов, улучшения качества потомства следует предусматривать на региональном уровне ${ }^{43}$ :

- возможность бесплатного приобретения витаминов, необходимых продуктов питания, пищевых добавок для беременных из социально незащищенных слоев населения; бесплатное оздоровление нуждающихся беременных в пансионатах, домах отдыха и однодневных стационарах;

43 Концепция охраны репродуктивного здоровья населения России на 20002004 годы // АВ. Охрана репродуктивного здоровья населения на 2000-2004 гг. 2001. - Вып. 8 [Электронный ресурс]. - Режим доступа: http://iam.duma.gov.ru/ node $/ 8 / 4534 / 15428$ 
- разработку на базе профильных НИИ специальных продуктов питания для беременных с повышенным содержанием железа, йода и других микроэлементов, пищевых добавок;

- для профилактики врожденных пороков развития обеспечение бесплатным медико-генетическим консультированием вступающих в брак молодоженов.

Осуществлять среди всех слоев населения систему гигиенического обучения и воспитания здорового образа жизни, ценности семьи.

Совершенствовать технологии, обеспечивающие гигиеническую и санитарную безопасность пациентов и медицинского персонала в лечебно-профилактических учреждениях.

\section{2. ТЕЧЕНИЕ БЕРЕМЕННОСТИ И РОДОВ У ЖЕНЩИН С НЕДИФФЕРЕНЦИРОВАННОЙ ДИСПЛАЗИЕЙ СОЕДИНИТЕЛЬНОЙ ТКАНИ}

В первом триместре беременности в группе женщин с НДСТ в большей степени проявляются следующие осложнения: ранний токсикоз и угроза прерывания беременности, что, однако, не может быть статистически достоверным.

Статистически достоверными $(\mathrm{p}<0,05)$ оказались осложнения в группе женщин с НДСТ, связанные с наличием воспалительных заболеваний половых путей, например кольпитов и вагинитов неспецифической этиологии, и анемии. Необходимо отметить, что уровень эритроцитов и уровень гемоглобина у беременных без НДСТ был заметно ниже аналогичных показателей в контрольной группе $(\mathrm{p}=0,014$ и $\mathrm{p}=0,0009)$. В большей степени у женщин с недифференцированной дисплазией соединительной ткани в первом триместре беременности наблюдались следующие осложнения: угроза прерывания беременности и воспалительные заболевания половых путей.

Кроме того, нельзя исключать тот факт, что наличие и выраженность угрозы прерывания статистически находились в обратной корреляционной зависимости с уровнем тромбоцитов $(\mathrm{R}=-0,42$; $\mathrm{p}=0,0095)$.

Во втором триместре беременности в группе женщин с НДСТ, как и среди женщин контрольной группы, в большей степени про- 
являлась анемия, которая имеет очень высокую степень распространенности у женщин с недифференцированной дисплазией соединительной ткани.

Необходимо учитывать и тот факт, что в большинстве случаев у женщин с недифференцированной дисплазией соединительной ткани в первом и втором триместре плод еще со стадии эмбриона развивается в условиях недостатка кислорода, который зависит от наличия гемического фактора. В подтверждение этому у беременных женщин с НДСТ во втором триместре присутствуют низкие показатели уровня эритроцитов с высокой степенью достоверности $(\mathrm{R}=-0,5266, \mathrm{p}=0,0003)$ коррелируют с развитием фетоплацентарной недостаточности в третьем триместре беременности, которая затем верифицируется гистологически.

У женщин с НДСТ в большей степени проявляется такое осложнение, как низкая плацентация. Еще одним фактом, на который указывает в своей работе А.В. Маслеников, является наличие у женщин с НДСТ в большей степени угрозы прерывания беременности во втором триместре, особенно ярко это проявляется, если у женщины присутствуют низкие показатели тромбоцитов в 1 триместре беременности $(\mathrm{R}=-0,4149, \mathrm{p}=0,0095)$, и именно с низким содержанием тромбоцитов коррелирует такое осложнение, как низкая плацентация $(\mathrm{R}=$ $-0,3876, p=0,0162)^{44}$. Других достоверных корреляций низкого уровня тромбоцитов в первом триместре беременности с осложнениями по триместрам и в родах не обнаружено.

Отметим, что угроза прерывания беременности во втором триместре положительно коррелировала со значениями гемостаза беременных женщин с НДСТ, как индекс АПТВ $(\mathrm{R}=0,5584, \mathrm{p}=0,0379)$ и тромбиновое время $(\mathrm{R}=0,5584, \mathrm{p}=0,0379)$ во втором триместре.

В третьем триместре беременности в структуре осложнений гестации все еще преобладало такое осложнение, как анемия, частота встречаемости которой достигает более чем 64\% у женщин с НДСТ.

Уровень гемоглобина в третьем триместре является отрицательным, с очень высокой степенью достоверности коррелирует со временем излития околоплодных вод относительно начала родовой

\footnotetext{
44 Масленников А.В. Особенности течения беременности и родов у женщин с недифференцированной дисплазией соединительной ткани: Дис. ... канд. мед. наук. - Уфа, 2014. - 116 с.
} 
деятельности $(\mathrm{R}=0,5825, \mathrm{p}=0,00008)$ - то есть в группе женщин с низкими показателями гемоглобина излитие околоплодных вод происходило раньше начала родовой деятельности.

Кроме того, в третьем триместре у женщин с НДСТ присутствовали прогностические маркеры, которые свидетельствовали о развитии угрозы преждевременных родов, отмечалось наличие миопии $(\mathrm{R}=0,46, \mathrm{p}=0,002)$, повышенные уровни индекса АПТВ $(\mathrm{R}=0,547, \mathrm{p}=0,0005)$ и РФМК $(\mathrm{R}=0,48, \mathrm{p}=0,002)$.

Самую сильную связь с фактом развития и прогрессирования гестоза имел феномен прогрессирующего снижения уровня тромбоцитов во время беременности $(\mathrm{R}=-0,488, \mathrm{p}=0,00139)$.

Достоверная (уровень $\mathrm{p}<0,03)$ сильная $(\mathrm{R}=+0,866)$ взаимосвязь была определена между развитием гестоза в третьем триместре и сдвигом в первом триместре беременности в сторону гиперкоагуляции таких показателей, как индекс АПТВ, протромбин по Квику, МНО, тромбиновое время, фибриноген и уровень РФМК. С данными параметрами были связаны гипоксии плода и факт обнаружения синдрома задержки развития плода в третьем триместре беременности, сила и достоверность связи была идентичной таковым для гестоза, что доказывает общность патогенеза этих осложнений у беременных с НДСТ.

\section{3. АЛГОРИТМ ВЕДЕНИЯ БЕРЕМЕННОСТИ И РОДОВ У ЖЕНЩИН С НЕДИФФЕРЕНЦИРОВАННОЙ ДИСПЛАЗИЕЙ СОЕДИНИТЕЛЬНОЙ ТКАНИ}

По результатам данных, полученных на первом этапе исследования, был выработан алгоритм ведения пациенток с недифференцированной дисплазией соединительной ткани.

При первой явке женщины в женскую консультацию должен быть верифицирован диагноз «недифференцированная дисплазия соединительной ткани».

Если наличие НДСТ подтвердилось, то необходимо в сроки, приближенные к остальному объёму обследований, провести расширенную гемостазограмму, включающую определение количества тромбоцитов, времени свертывания крови, время кровотечения, агрегации тромбоцитов, активированного частичного тромбопластинового времени (далее - АЧТВ), фибриногена, определение 
протромбинового (тромбопластинового) времени, МНО, содержания растворимых фибрин-мономерных комплексов, протромбина по Квику, фибриногена В, антитромбина III, Д-димеров, уровня протеина С.

Кроме того, необходимо, чтобы пациентку проконсультировал хирург и терапевт на предмет наличия экстрагенитальной патологии, характерной для НДСТ.

После выполнения первого блока анализов необходимо начать профилактические мероприятия в виде назначения диеты с повышенным содержанием олигопептидов и гликозаминогликанов, принятием магния $\mathrm{B}_{6}$, то есть осуществление магниевой терапии. Магний $\mathrm{B}_{6}$ назначается по 2 таблетки 2 раза в день с момента установления беременности и до 36 недель. При обнаружении хронической венозной недостаточности можно назначить диосмин 600 мг в день, длительность курса - 4 недели, повторно раз в триместр.

Значимые изменения зарегистрированы при анализе показателей оксипролина и магния в процессе магниевой терапии. Если до начала лечения уровень оксипролина у женщин с НДСТ значительно превышал таковой у женщин контрольной группы, то на фоне лечения происходила выраженная нормализация уровня оксипролина к 22 неделям (на 50\%), а к 34 неделям зарегистрировано его абсолютное соответствие уровню контрольной группы. Тогда как в подгруппе 1 основной группы наблюдалось статистически значимое повышение уровня оксипролина, свидетельствующее о прогрессирующей деградации коллагенов с увеличением срока беременности за счет тканей материнского и/или плодового происхождения.

Прием магния приводит к полной нормализации показателя к 22 неделям и незначительному его превалированию $(11,4 \%)$ в 34 недели беременности (P > 0,05). Уровень магния в крови беременных с НДСТ, не получавших препараты магния, оставался стабильным на протяжении всей беременности.

В зависимости от показателей гемостазиограммы необходимо выделять группы риска по таким осложнениям, как плацентарная недостаточность, хроническая внутриутробная гипоксия и задержка внутриутробного развития плода - в случае выявления низ- 
ких (менее 50\%) функциональных показателей агрегационной активности тромбоцитов, а также гестоз - в случае высоких значений РФМК в 1 и 2 триместре беременности, роста уровня Д-димеров в эти же сроки и явлений дезадаптации в системе гемостаза с ранних сроков беременности.

Повторять расширенное исследование целесообразно не чаще 1 раза в триместр. Последнее исследование необходимо проводить на сроке 36 недель для определения состояния системы гемостаза, риска кровотечений (в случае выраженной дезадаптации коагуляционного гемостаза или угнетения сосудисто-тромбоцитарного гемостаза).

Применение подобного алгоритма ведения в группе из 800 пациенток позволит улучшить акушерские и перинатальные исходы после проведения данного курса лечения.

В первом триместре беременности в группах женщин с НДСТ достоверных различий по частоте встречаемости осложнений и их структуре не было.

Во втором триместре беременности во 2 группе женщин с НДСТ удалось добиться снижения частоты встречаемости таких осложнений, как угроза прерывания беременности и анемия. В третьем триместре у женщин второй группы снизилась частота угрозы прерывания, анемии, гестоза и гипоксии плода $(\mathrm{p}<0,05)$. Но не было зафиксировано снижение частоты встречаемости таких осложнений, как низкая плацентация и синдром задержки внутриутробного развития плода.

В первой группе беременных женщин с НДСТ процент экстренных оперативных родоразрешений составил 19,2\%, во второй группе аналогичный показатель был равен только 11,9\%. В структуре показаний к экстренному разрешению у женщин с НДСТ на первом месте находились признаки нарастающей гипоксии плода, на втором - аномалии родовой деятельности. На третьем (только в 1 группе) - преждевременная отслойка нормально расположенной плаценты. Во второй группе этот диагноз не фиксировался.

Срок родов в 1 группе составил 38 недель, во второй - 38, в третьей - 39,5 недель. Излитие околоплодных вод до срока 37 недель встречалось у 3 (4,1\%) женщин из 1 группы и у 1 (2,4\%) женщины из второй группы. В контрольной группе все эпизоды преждевременного излития околоплодных вод происходили на сроке более 38 недель. 
Вес новорожденных женщин с НДСТ был достоверно меньше, чем аналогичный показатель у здоровых женщин, $\mathrm{p}<0,004$ при сравнении всех групп.

Аналогичная динамика наблюдалась и для роста новорожденных, $\mathrm{p}<0,0003$ для групп сравнения. В то же время вес новорожденных во 2 группе был несколько больше, чем в первой группе

Обращают на себя внимание сниженные показатели оценки новорожденных по шкале Апгар в группах женщин с НДСТ, так, для 1 группы средние значения этого показателя составили 8 баллов, для второй группы - также 8 баллов, а для 3 группы - 8 баллов. Различия в тесте сравнения Манна - Уитни между показателями новорожденных женщин с НДСТ и женщин без НДСТ были достоверными $(\mathrm{p}<0,005)$. Только 51\% новорожденных в 1 группе имел оценку на первой минуте 8 баллов. Оценки по школе Апгар 9 баллов и более на первой минуте не было ни у одного новорожденного. В то же время обращает на себя внимание тот факт, что во второй группе суммарный процент детей, родившихся с оценкой по шкале Апгар 5 и 6 баллов, был меньше, чем аналогичный показатель в 1 группе (10\% и 23\% соответственно).

Хроническая фетоплацентарная недостаточность в доношенном сроке встречалась у 31,5\% женщин 1 группы и у 28,6\% женщин 2 группы, на этом фоне задержка внутриутробного развития развилась у 5,5\% и 4,7 \% женщин соответственно. Женщины контрольной группы не имели хронической фетоплацентарной недостаточности.

Травмы родовых путей встречались у 26,1\% женщин контрольной группы, в группе женщин с НДСТ на ретроспективном этапе этот показатель составил 35,6\%, на проспективном - 33,3\%. Структура акушерского травматизма у пациенток на этапах исследования отражена в диаграмме на рисунке 34. У трёх женщин из 1 группы была обнаружена гематома влагалища, потребовавшая вскрытия и прошивания. Во второй группе такого осложнения зафиксировано не было.

У 11\% женщин 1 группы были зафиксированы осложнения в виде акушерских кровотечений, аналогичный показатель у женщин 2 группы был меньше и составил 9,5\%.

Таким образом, из представленных данных видно, что предложенный алгоритм ведения беременных с НДСТ оказывает благоприятное влияние на акушерские и перинатальные исходы. 


\section{ГЛАВА 5. СХЕМА ВЕДЕНИЯ БЕРЕМЕННОСТИ ЖЕНЩИН С НЕДИФФЕРЕНЦИРОВАННОЙ ДИСПЛАЗИЕЙ СОЕДИНИТЕЛЬНОЙ ТКАНИ}

Любое ведение беременности акушером-гинекологом, как и обследование больных другим врачом, подчинено определенному алгоритму необходимых действий, который может быть представлен в виде схемы с последующим описанием каждого пункта данной схемы.

Схематически ведение беременности женщин с недифференцированной дисплазией соединительной ткани условно можно разделить на два основных направления:

1. Ведение условно здоровой женщины.

2. Ведение женщины, которая знала до беременности, что она больна дисплазией соединительной ткани.

Каждое из данных направлений включает в себя необходимый алгоритм действий. Рассмотрим каждое из данных направлений.

\section{1. ВЕДЕНИЕ БЕРЕМЕННОСТИ УСЛОВНО ЗДОРОВОЙ ЖЕНЩИНЫ}

При отсутствии видимых проявлений недифференцированной дисплазии соединительной ткани или фиксации в медицинской карте наличия НДСТ беременная может считаться условно здоровой женщиной. В данном случае необходимо назначить консультацию и осмотр терапевта для того, чтобы определить наличие или отсутствие фенотипических маркеров НДСТ.

Среди внешних проявлений недифференцированной дисплазии соединительной ткани широко распространены такие, как:

1) астеническое телосложение, то есть у женщины наблюдается сужение всех конечностей, включая и грудную клетку, они имеют продолговатую форму лица, а руки при этом будут непропорциональны по длине. Еще одним признаком данного заболевания является бледность кожи;

2) аномалия прикуса, к которым относят дистальный прикус (недоразвитость нижней челюсти, но в большей степени развита 
верхняя челюсть), мезиальный прикус (противоположен дистальному прикусу), открытый прикус (часть зубов не смыкаются и образуют щель), глубокий прикус (резцы верхнего ряда перекрывают резцы нижнего ряда), перекрёстный прикус (слабо развита какаялибо сторона любой челюсти), дистопия (зубы находятся не на своем месте в зубном ряду), диастема встречается чаще всего, для нее характерно наличие щели между центральными резцами верхней челюсти, намного реже нижней челюсти;

3) искривленные мизинцы, то есть пальцы скошены медиально или латерально, что является частным проявлением такого заболевания, как клинодактилия;

4) сколиоз, искривления позвоночника, чаще всего встречаются незначительные искривления позвоночника грудного отдела;

5) плоскостопие, то есть происходит опущение поперечного и продольного свода;

6) миопия, то есть близорукость.

К числу висцеральных фенотипических маркеров относят:

1) аномалии сердечно-сосудистой системы, например: гипоплазия левого сердца (недоразвитость сердца с левой стороны, которая может привести к летальному исходу); транспозиция магистральных сосудов (дискордантное желудочково-артериальное соединение) и так далее;

2) аномалии мочевой системы, например: поражение почек (органы, очищающие кровь и образующие мочу), мочеточников (каналы, ведущие от почек до мочевого пузыря), мочевого пузыря (орган, в котором содержится моча), уретры (канал, через который моча высвобождается из мочевого пузыря);

3) варикозное расширение вен нижних конечностей.

Согласно исследованию, проведенному Т.С. Лукиной, чаще всего у женщин с недифференцированной дисплазией соединительной ткани встречается проявление дизэмбриогенеза ${ }^{45}$, то есть небольшие внешние фенотипические проявления недифференцированной дисплазии соединительной ткани. Они есть у каждого человека, но при отсутствии дисплазии соединительной ткани число

45 Лукина Т.С. Оптимизация математического моделирования и прогнозирования анализа течения беременности и родов у женщин с недифференциальной дисплазией соединительной ткани: Автореф. дис. ... канд. мед. наук. - М., 2003. - 57 с. 
данных аномалий или стигм не должно превышать 5, к числу стандартных аномалий можно отнести широкую переносицу, неправильную форму ушной раковины и т. д.

Кроме того, терапевт вправе проводить антропометрические исследования, которые основываются на следующих измерениях:

- длина верхней конечности - расстояние между выступающей точкой на краю акромиального отростка лопатки и дистальной точкой ногтевой фаланги 3-го пальца;

- длина плеча - расстояние от выступающей точки на краю акромиального отростка лопатки до верхней точки головки лучевой кости;

- длина предплечья - расстояние от нижней точки шиловидного отростка лучевой кости до верхней точки головки лучевой кости;

- длина кисти - расстояние между проекцией шиловидной кости на продолжение линии третьей пястной кости до самой дистальной точки ногтевой фаланги 3-го пальца;

- длина нижней конечности - расстояние от большого вертела до пола;

- длина бедра - расстояние между верхним краем лонного сочленения и серединой медиального мыщелка большеберцовой кости;

- длина голени - расстояние между серединой медиального мыщелка большеберцовой кости и нижней точкой на внутренней лодыжке;

- длина стопы - расстояние от пяточного бугра до конца ногтевой фаланги 2-го пальца.

В ходе данной консультации терапевт уже устанавливает наличие или отсутствие у женщин признаков недифференцированной дисплазии соединительной ткани.

Если у женщины обнаружены фенотипические признаки недифференцированной дисплазии соединительной ткани и есть астенические жалобы, то необходимо проведение специальных приемов по невынашиванию беременности, которые проводятся хотя бы до 12 недель.

Если же у женщины отсутствуют фенотипические признаки недифференцированной дисплазии соединительной ткани и есть астенические жалобы, то дальнейшее наблюдение осуществляет участковым акушером-гинекологом. 


\section{2. ВЕДЕНИЕ ЖЕНЩИНЫ, КОТОРАЯ ЗНАЛА ДО БЕРЕМЕННОСТИ, ЧТО ОНА БОЛЬНА ДИСПЛАЗИЕЙ СОЕДИНИТЕЛЬНОЙ ТКАНИ}

Многие женщины, находясь еще в юношеском возрасте, узнают о наличии недифференцированной дисплазии соединительной ткани, что фиксируется в их медицинских картах. При наличии у беременных женщин диагноза НДСТ до беременности в первую очередь необходимо проведение специализированного приема, который проводится до 12 недель. В ходе данного приема производятся исследования отсутствия висцеральных проявлений НДСТ, оксипролина и магния в сыворотке крови.

После проведения специализированного приема необходимо провести расчет оценки риска, который основывается на данных программы «Step DST», работа и преимущества которой были описаны выше.

По группам риска женщины с НДСТ относятся к:

1. Группам низкого риска, то есть их фенотипические признаки НДСТ в меньшей степени влияют на ход и итог беременности и родов. Данная группа, как и женщины, у которых отсутствует диагноз НДСТ, в дальнейшем наблюдается участковым акушером-гинекологом.

2. Группам высокого риска, то есть их фенотипические признаки НДСТ могут привести к акушерским осложнениям беременности и родов. Именно женщины данной группы нуждаются в проведении магниевой терапии, однако женщина может отказаться от данного лечения и наблюдаться у участкового акушера-гинеколога, но при этом осуществляется консультация и помощь медицинского психолога.

В том случае, если женщина, относящаяся к группе высокого риска по НДСТ, не отказывается от проведения терапии препаратами магния, осуществляется контроль уровня магния и оксипролина на 22 и 34 неделях, что помогает корректировать дозировку магния и при необходимости ее менять. А госпитализация пациентки из группы высокого риска планируется на 38 неделе беременности, если нет основания для госпитализации на сроке раньше, чем 38 недель беременности.

Однако необходимо отметить, что не все пациентки с НДСТ из группы высокого риска обладают достаточным финансированием для проведения терапии магниевыми аппаратами, поэтому им необходимо произвести дополнительное финансирование, которое 
осуществляется государством, что предполагает наличие бесплатных услуг и препаратов для беременных.

Существует конкретный перечень услуг и препаратов, которые беременная женщина может получить бесплатно в качестве дополнительного финансирования, что фиксируется в следующих нормативно-правовых актах:

1. Письмо от 16 июля 2007 г. №15-4/1360-09 об оказании платных услуг во время беременности и родов (с изм., внесенными письмом Минздравсоцразвития РФ от 13.11.2007 №15-4/2187-09). Согласно которому «оказание платных медицинских услуг не может осуществляться в ущерб гарантированному объему бесплатной медицинской помощи».

2. Приказ от 14 сентября 2006 г. №662 об утверждении стандарта медицинской помощи женщинам с нормальным течением беременности. В нем фиксируется перечень необходимых медицинских обследований как непосредственно специалистами, так и требующие специализированного оборудования (анализы, УЗИ и прочее).

3. Письмо от 13 ноября 2007 г. №15-4/2187-09 определяет общие положения платного обслуживания беременных женщин, то есть то, что не выходит за рамки дополнительного финансирования государством.

4. Приказ от 19 января 2007 г. №50 «О порядке и условиях расходования средств, связанных с оплатой государственным и муниципальным учреждениям здравоохранения услуг по медицинской помощи, оказанной женщинам в период беременности, в период родов и послеродовой период, а также по диспансерному наблюдению ребенка в течение первого года жизни».

Отметим, что для того чтобы использовать дополнительное финансирование, необходимо наличие полиса ОМС, который действует лишь в государственных органах здравоохранения. В таблице 4 представлен частичный перечень бесплатных услуг, которые позволяют получить полис ОМС беременной женщине.

Таблица 4

Перечень услуг

\begin{tabular}{|l|c|c|}
\hline \multicolumn{1}{|c|}{ Наименование } & $\begin{array}{c}\text { Частота } \\
\text { предоставления }\end{array}$ & $\begin{array}{c}\text { Среднее } \\
\text { количество }\end{array}$ \\
\hline Сбор анамнеза и жалоб в гинекологии & 1 & 15 \\
\hline Визуальное исследование в гинекологии & 1 & 12 \\
\hline
\end{tabular}


Глава 5. Схема ведения беременности женщин с недифференцированной дисплазией соединительной ткани

\begin{tabular}{|l|c|c|}
\hline Пальпация в гинекологии & 1 & 12 \\
\hline Исследование пульса & 1 & 12 \\
\hline $\begin{array}{l}\text { Измерение артериального давления на пе- } \\
\text { риферических артериях }\end{array}$ & 1 & 12 \\
\hline Измерение размеров матки & 1 & 8 \\
\hline $\begin{array}{l}\text { Аускультация плода с помощью стето- } \\
\text { скопа }\end{array}$ & 1 & 8 \\
\hline Пальпация плода & 1 & 8 \\
\hline Измерение массы тела & 1 & 12 \\
\hline Осмотр шейки матки в зеркалах & 1 & 1 \\
\hline Получение цервикального мазка & 1 & 2 \\
\hline Получение влагалищного мазка & 1 & 2 \\
\hline Ультразвуковое исследование плода & 1 & 3 \\
\hline Кардиотокография плода & 1 & 3 \\
\hline Подготовка беременных к родам & 1 & 3 \\
\hline Обучение уходу за новорожденным & 1 & 3 \\
\hline Психологическая адаптация & 1 & 12 \\
\hline Аутогенная тренировка & 1 & 3 \\
\hline $\begin{array}{l}\text { Пособие по наложению бандажа при бе- } \\
\text { ременности }\end{array}$ & 1 & 12 \\
\hline $\begin{array}{l}\text { Назначение лекарственной терапии при } \\
\text { беременности }\end{array}$ & 1 & 1 \\
\hline $\begin{array}{l}\text { Назначение диетической терапии при бе- } \\
\text { еменности }\end{array}$ & 1 & 1 \\
\hline $\begin{array}{l}\text { Назначение лечебно-оздоровительного } \\
\text { режима при беременности }\end{array}$ & 1 & 1 \\
\hline Взятие крови из пальца & 1 & 1 \\
\hline Взятие крови из периферической вены & 1 & 2 \\
\hline Исследование уровня лейкоцитов в крови & 1 & 1 \\
\hline
\end{tabular}

К списку препаратов, которые могут предоставляться бесплатно, относят фолиевую кислоту, витамин Е, кальция карбонат и т. д. Однако данный перечень каждый год может изменяться Министерством здравоохранения. 


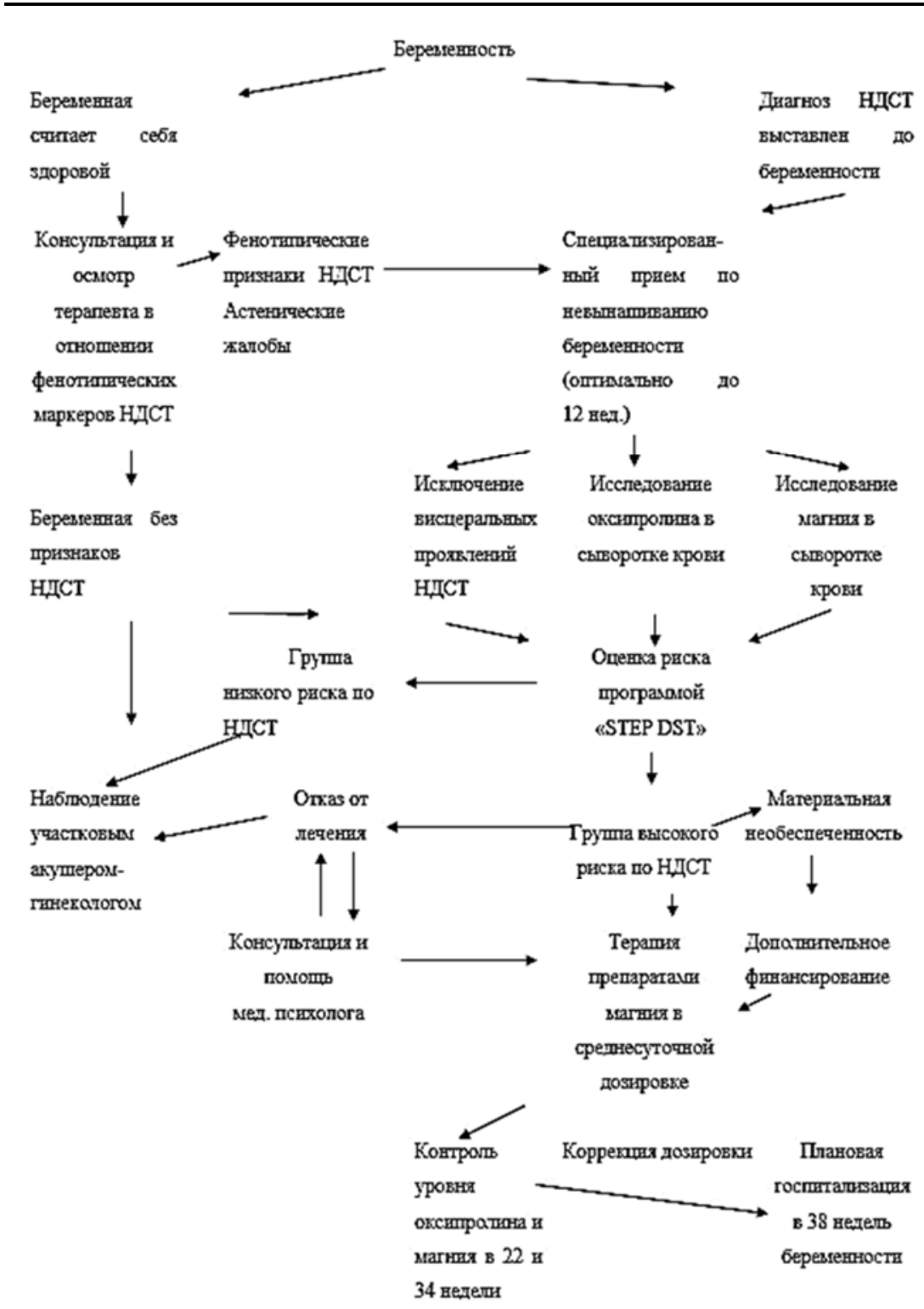

Рисунок 4. Схема медико-социальной поддержки и ведения беременных женщин с НДСТ 


\section{3. ТАКТИКА ВЕДЕНИЯ БЕРЕМЕННОСТИ И РОДОВ У ЖЕНЩИН С НЕДИФФЕРЕНЦИРОВАННОЙ ДИСПЛАЗИЕЙ СОЕДИНИТЕЛЬНОЙ ТКАНИ}

В данной части работы описывается ведение беременных группы высокого риска, у которых возможны акушерские осложнения беременности и родов.

Проанализируем принципы ведения пациенток группы высокого риска по развитию плацентарных нарушений и гестоза, на ранней стадии необходима диагностика, затем последовательно проводится доклиническая профилактика осложнений в критические сроки гестации, связанных с первой и второй волной инвазии трофобласта, обоснованное по срокам и составу комплексное лечение.

На доклиническом этапе обследования образуются группы беременных в зависимости от наличия или возможности формирования той или иной патологии. Для женщин с диагнозом НДСТ группы различаются по срокам беременности:

1) для первой половины срока гестации это группы риска по раннему токсикозу и угрозе прерывания;

2) для второй половины указанного срока - это плацентарные нарушения и гестоз, внутриутробная гипоксия и задержка внутриутробного развития плода, преждевременное излитие околоплодных вод, акушерские кровотечения и аномалии родовой деятельности.

Одним из наиболее частых осложнений для развития плода и исхода родов является значение состояние гемостаза.

В связи с этим у беременных с НДСТ помимо указанной схемы можно использовать алгоритм клинико-гемостазиологических исследований. Один из последних таких алгоритмов был предложен П.А. Кирющенковым с соавторами. Он обобщает существующие анамнестические данные, анализ клинической ситуации с выполнением общих оценочных, а при необходимости - отдельных специальных гемостазиологических тестов, установление диагноза и подбор необходимой терапии ${ }^{46}$.

\footnotetext{
46 Causal relationship between hyperfibrinogenemia, thrombosis, and resistance to thrombolysis in mice / K.R. Machlus, J.C. Cardenas, F.C. Church, A.S. Wolberg // Blood. - 2011. - Vol. 117. - P. 4953-4963.
} 
При наличии любой патологии беременной женщины с НДСТ в первом триместре рекомендуется специальная диета, которая характеризуется повышенным содержанием белков и гликозаминогликанов, то есть тех веществ, которые позволяют регулировать тонус и моторику желудочно-кишечного тракта, витамин Е в дозе $400 \mathrm{ME} /$ сутки. При назначении тех или иных препаратов необходимо учитывать, что препараты, понижающие коагуляционный потенциал, могут привести к снижению геморрагических проявлений у женщин с синдромом мезенхимальной дисплазии. Кроме того, необходимо помнить, что дисплазия соединительной ткани в большинстве случаев характеризуется облигатным магниево-дефицитным состоянием ${ }^{47}$.

Согласно данным исследования В.Е. Радзинского профилактическое назначение магния является важной и обязательной частью этиопатогенетической терапии. Она позволяет своевременно купировать гипервозбудимость матки, кроме того, является одним из основных способов профилактики задержки внутриутробного роста плода.

В работе Л.Б. Лазебника и соавторов, написанной в 2010 году, присутствует описание взаимосвязи концентрации магния в крови пациенток с НДСТ с развитием геморрагического синдрома на фоне НДСТ. Геморрагический синдром у данного типа пациенток характеризуется ангиопатичностью, что, в свою очередь, связано с магнием, что проявляется снижением плотности сосудистой стенки, обусловленной деградацией коллагеновых и, как следствие, эластических волокон, а также полисахаридных гиалуроновых нитей ${ }^{48}$.

Лечение беременных с диагнозом НДСТ проводится посредством назначения таблетированных препаратов магния, что фиксируется в общей схеме ведения беременных женщин с НДСТ и считается оправданным с позиции рациональной фармакотерапии беременных. Кроме того, данное лечение может проводиться без лабораторного подтверждения магниевого дефицита в связи с малой его информативностью. Еще одной причиной проведения своевременного лечения

${ }^{47}$ Шабалов Н.П. Наследственные болезни соединительной ткани / Н.П. Шабалов, В.Г. Арсентьев // Педиатрия. Национальное руководство: В 2 т. - М.: ГЭОТАРМедиа, 2009. - Т. 1. - С. 298-320.

${ }^{48}$ Способ объективизации диагностики недифференцированной дисплазии соединительной ткани у детей с помощью количественного метода / О.В. Сидорович, В.И. Горемыкин, С.Ю. Елизарова, О.В. Нестеренко // Международный журнал экспериментального образования. - 2013. - №11-2. - С. 53-55. 
таблетированными препаратами магния является то, что магний необходим для нормализации состояния системы гемостаза ${ }^{49}$.

Для профилактики и коррекции гиперкоагуляционных нарушений в системе гемостаза у беременных женщин группы высокого риска по развитию тромботических осложнений применяются низкомолекулярные гепарины (НМГ), которые иногда даже называют «золотым стандартом» профилактической антикоагулянтной терапии. Но, учитывая тромбогеморрагический характер проявлений нарушений гемостаза у пациентов с НДСТ, к назначению препаратов этой группы надо подходить осторожно. Для пациентов этой группы оптимально использовать методы неспецифической профилактики (эластическая компрессия нижних конечностей, диета и т. д.), а также назначение флеботоников. Флеботоники, кроме всего прочего, являются важным компонентом алгоритма ведения беременных с НДСТ в ситуации, когда у последних обнаруживаются явления хронической венозной недостаточности.

Одним из популярных флеботоников, способных оказывать нормализующее влияние на состояние системы гемостаза, считается диосмин 600 мг.

Если же отмечается наличие развития акушерских кровотечений, основные методы лечения должны содержать в себе средства местного и общего действия.

С целью коррекции геморрагического синдрома у пациентов с НДСТ применяются средства местного и общего действия. Для остановки кровотечения местно чаще всего используются хирургические методы, гемостатическая губка, системно - препараты антифибринолитического действия, прежде всего - транексамовая кислота. По общепринятым показаниям - инфузионно-трансфузионная терапия. При массивных кровопотерях оправдано применение рекомбинантных факторов свёртывания крови.

\footnotetext{
${ }^{49}$ Кудинова Е.Г. Генетические тромбофилии у девушек с мезенхимальными дисплазиями / Е.Г. Кудинова // Сибирский медицинский журнал. - 2011. - Т. 26. №3. - Вып. 2. - С. 97-99.
} 
Научное издание

Фадеева Татьяна Сергеевна

\title{
ДИСПЛАЗИЯ СОЕДИНИТЕЛЬНОЙ ТКАНИ: НОВЫЕ ГОРИЗОНТЫ ПРОБЛЕМЫ
}

\author{
Монография \\ Чебоксары, 2018 г. \\ Редактор T.С. Фадеева
}

Корректоры Е.В. Кузнеиова, С.Ю. Семенова

Компьютерная верстка и правка С.Ю. Семенова

Дизайн обложки Н.В. Фирсова

Подписано в печать 31.01.2019 г.

Дата выхода издания в свет 05.02.2019 г.

Формат 60×84/16. Бумага офсетная. Печать офсетная.

Гарнитура Times. Усл. печ. л. 4,4175. Заказ К-442. Тираж 500 экз.

Издательский дом «Среда»

428005, Чебоксары, Гражданская, 75, офис 12

+7 (8352) 655-731

info@phsreda.com

https://phsreda.com

Отпечатано в Студии печати «Максимум»

428005, Чебоксары, Гражданская, 75

+7 (8352) 655-047

info@maksimum21.ru

www.maksimum21.ru 